\title{
Article
}

\section{Transcriptomic Changes in Internode Explants of Stinging Nettle during Callogenesis}

\author{
Xuan Xu (D), Sylvain Legay, Roberto Berni, Jean-Francois Hausman (D) and Gea Guerriero *(D) \\ Environmental Research and Innovation Department, Luxembourg Institute of Science and Technology, 5, Rue \\ Bommel, Hautcharage, L-4940 Luxembourg, Luxembourg; xuan.xu@list.lu (X.X.); sylvain.legay@list.lu (S.L.); \\ roberto.berni@list.lu (R.B.); jean-francois.hausman@list.lu (J.-F.H.) \\ * Correspondence: gea.guerriero@list.lu; Tel.: +352-275-8885-096
}

check for updates

Citation: Xu, X.; Legay, S.; Berni, R.; Hausman, J.-F.; Guerriero, G. Transcriptomic Changes in Internode Explants of Stinging Nettle during Callogenesis. Int. J. Mol. Sci. 2021, 22, 12319. https://doi.org/10.3390/ ijms222212319

Academic Editor: Zsófia Bánfalvi

Received: 21 October 2021

Accepted: 10 November 2021

Published: 15 November 2021

Publisher's Note: MDPI stays neutral with regard to jurisdictional claims in published maps and institutional affiliations.

Copyright: (C) 2021 by the authors Licensee MDPI, Basel, Switzerland. This article is an open access article distributed under the terms and conditions of the Creative Commons Attribution (CC BY) license (https:// creativecommons.org/licenses/by/ $4.0 /)$.

\begin{abstract}
Callogenesis, the process during which explants derived from differentiated plant tissues are subjected to a trans-differentiation step characterized by the proliferation of a mass of cells, is fundamental to indirect organogenesis and the establishment of cell suspension cultures. Therefore, understanding how callogenesis takes place is helpful to plant tissue culture, as well as to plant biotechnology and bioprocess engineering. The common herbaceous plant stinging nettle (Urtica dioica L.) is a species producing cellulosic fibres (the bast fibres) and a whole array of phytochemicals for pharmacological, nutraceutical and cosmeceutical use. Thus, it is of interest as a potential multi-purpose plant. In this study, callogenesis in internode explants of a nettle fibre clone (clone 13) was studied using RNA-Seq to understand which gene ontologies predominate at different time points. Callogenesis was induced with the plant growth regulators $\alpha$-napthaleneacetic acid (NAA) and 6-benzyl aminopurine (BAP) after having determined their optimal concentrations. The process was studied over a period of 34 days, a time point at which a well-visible callus mass developed on the explants. The bioinformatic analysis of the transcriptomic dataset revealed specific gene ontologies characterizing each of the four time points investigated $(0,1,10$ and 34 days). The results show that, while the advanced stage of callogenesis is characterized by the iron deficiency response triggered by the high levels of reactive oxygen species accumulated by the proliferating cell mass, the intermediate and early phases are dominated by ontologies related to the immune response and cell wall loosening, respectively.
\end{abstract}

Keywords: callogenesis; transcriptomics; stinging nettle; qPCR; plant growth regulators

\section{Introduction}

Differentiated plant cells retain the ability to trans-differentiate to callus [1], i.e., lose their committed fate and re-enter the cell cycle, proliferate to produce a mass of cells known as callus and, under specific conditions and phytohormonal stimuli, regenerate tissues and whole organs [2]. This plasticity is at the base of many biotechnology-related applications, such as micropropagation, plant transformation and establishment of cell suspension cultures. Plant bioprocess engineering approaches are receiving much attention in the light of their use in industrially relevant applications, e.g., to produce phytochemicals with bioactivities of interest for the cosmetic and food industries $[3,4]$, as well as for the biopharmaceutical industry [5].

Among the plants of interest for the production of phytochemicals, e.g., for medicinal and antimicrobial applications, as well as for use in dietary supplements [6] and cosmetics [7], there is the common herbaceous species Urtica dioica L., also known as stinging nettle. Among the phenolic compounds of medicinal interest in nettle, it is worth mentioning lignans, whose abundance was shown to differ according to the tissues, i.e., aerial parts vs. roots [8]. Besides the production of phytochemicals, nettle is valued as a source of cellulosic fibres, the bast fibres [9,10], which can be used in biocomposites [11] and textiles [12]. More recently, carbon nanosheets with interesting physico-chemical properties, namely, 
interconnectivity of pores, graphitization, surface area and pore width [13], were prepared from stems of stinging nettles, which diversifies the application opportunities of this weed.

Establishing plant cell suspension cultures allows valued compounds to be produced on large scale [14], without having to source wild plants (thereby contributing to preserve native populations), or use lands, with lower environmental impact and completely independently of the season [4]. Callogenesis is a key step for the establishment of plant cultures. Molecular studies on the model plant Arabidopsis thaliana have allowed researchers to understand the mechanisms involved in plant callogenesis; such mechanisms involve the activation of the pathway mediating lateral root formation [15-17].

To establish plant cell cultures, tissue explants are cultivated on specific media containing a balance of growth regulators, i.e., auxins and cytokinins; the proliferating callus masses appearing are then separated and transferred to new media for their further growth. Established plant calli, i.e., sub-cultured over several weeks and showing a stable growth, are subsequently transferred to liquid media in shake flasks, usually containing the same balance of plant growth regulators (PGRs) and induced to disaggregate and form a homogeneous suspension culture. Hence, it is evident that the process of callogenesis is, at the same time, crucial and limiting for plant cell culture technologies and bioprocesses.

In the present study, callogenesis was studied from a molecular angle in stinging nettle, a plant for which no prior data exist and an herbaceous species holding great (and still under-exploited) industrial interest as a source of bioactive phytochemicals. The approach adopted relies on high-throughput sequencing of cDNA libraries prepared from stem segments at different steps of callogenesis, i.e., at 0, 1, 10 and 34 days.

\section{Results and Discussion}

\subsection{Identification of Optimal Concentrations of Plant Growth Regulators Promoting Callogenesis}

As a first step towards establishing an optimal protocol for callogenesis, different concentrations of the PGRs $\alpha$-napthaleneacetic acid (NAA) and 6-benzyl aminopurine (BAP) were tested. These PGRs belong to the auxin and cytokinin families, respectively, and were chosen since they are known to regulate callus formation through both cooperative and antagonistic interactions [18].

Square Petri plates divided into 25 small compartments each containing a different combination of the PGRs (Supplementary Figure S1) were used. The test was carried out using two Petri dishes (i.e., 2 biological replicates) over a period of 34 days, both in darkness (Figure 1a) and photoperiod (Figure 1b). The time points taken for analysis were $3,5,6,11,18$ and 34 days. As shown in Figure 1, calli formed at the extremities of the explants both in darkness and photoperiod. In darkness, roots appeared at the lowest concentrations of both NAA and BAP; at the highest concentration of NAA, calli appeared from day 11 onwards in darkness and photoperiod. At day 34, a well-developed creamy and compact green callus mass appeared in darkness and photoperiod, respectively, at the highest [NAA].

Since a creamy colored callus developed in darkness and considering that dark cultivation of cell suspension cultures is economically more convenient than adopting photoperiod, a subsequent experiment was established in which the callogenesis of nettle internodes was followed at $0,1,3,6,10,20$ and 34 days in the dark using the concentrations of $3 \mathrm{mg} / \mathrm{L}$ for NAA and $0.01 \mathrm{mg} / \mathrm{L}$ for BAP (Figure 2). These concentrations were very effective in inducing the development of a creamy mass of callus (Figure 2, insets).

As Figure 2 shows, ten explants were put on a single Petri plate (three Petri plates were prepared for a total of three biological replicates for each time point). Over the time-course, swelling of the extremities of the explants was evident from day 6 onwards (Figure 2d) and calli started to appear from day 10 (Figure 2e). At day 20 and 34, the calli increased progressively in mass (Figure 2f,g). Ten explants were pooled per Petri dish to prepare for RNA extraction and subsequent qPCR analysis. 
(a)

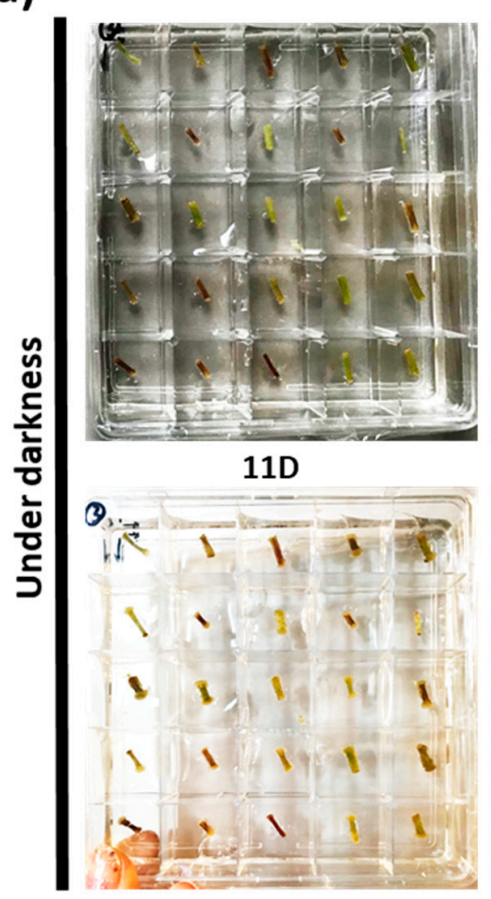

(b)

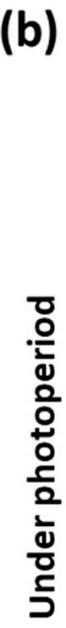

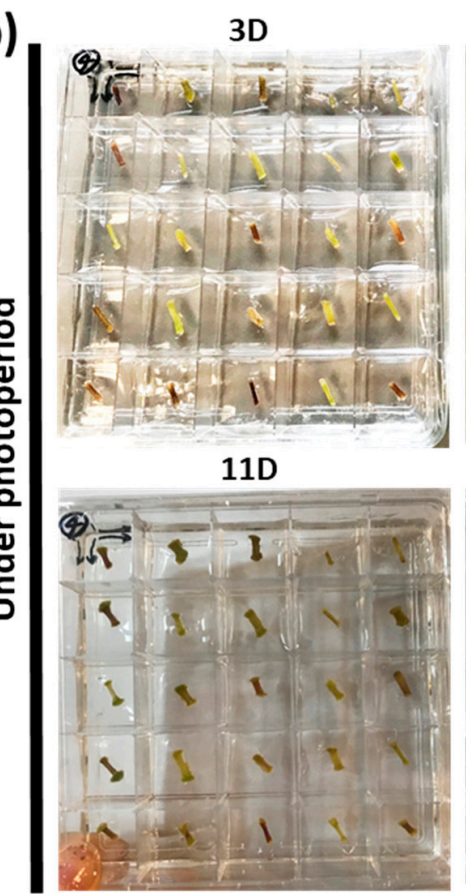
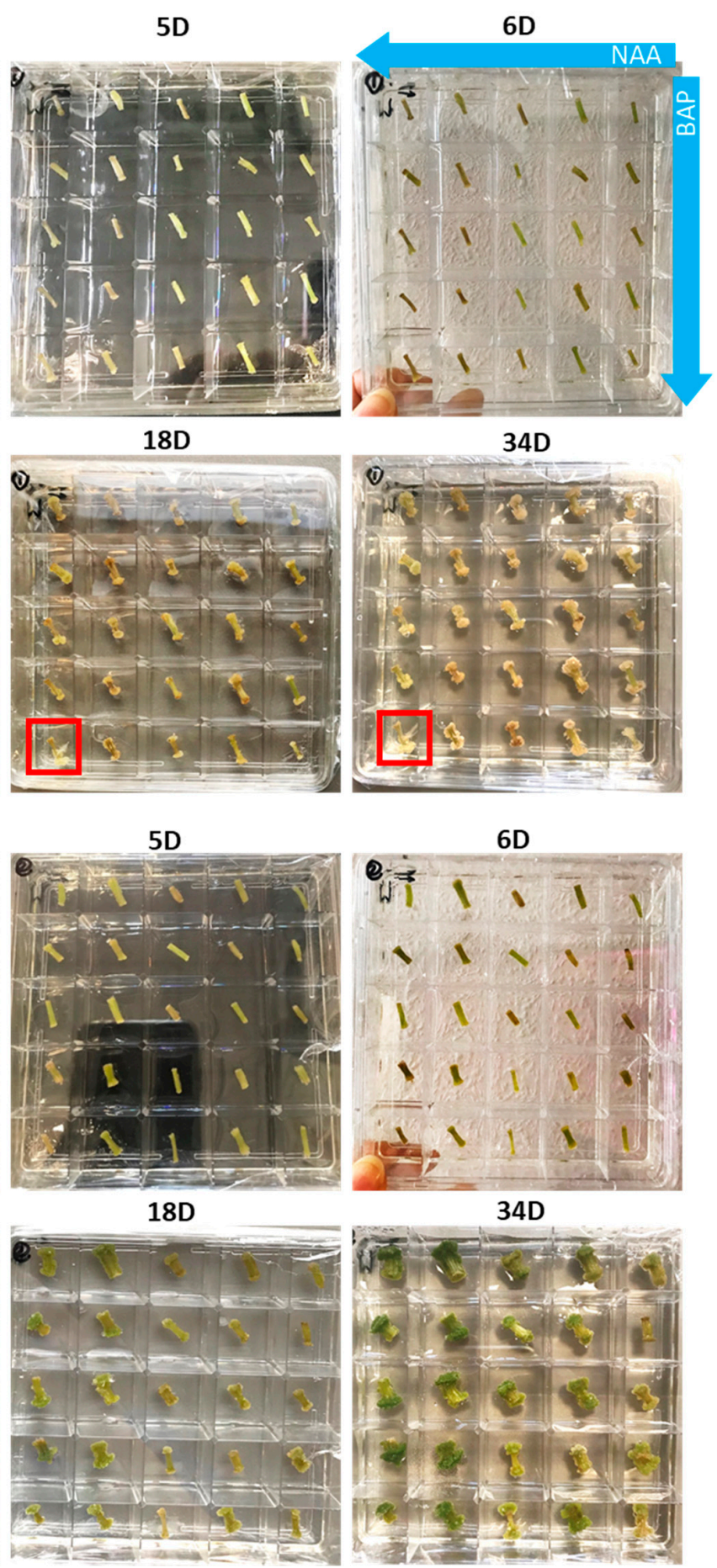

Figure 1. Pictures showing the effects of plant growth regulators at different concentrations and combinations on callogenesis of nettle explants at days 3, 5, 6, 11, 18 and 34 (D) in the dark (a) or photoperiod (b). The combination of different concentrations of NAA and BAP (i.e., 3, 1, 0.5, 0.1 and $0.01 \mathrm{mg} / \mathrm{L}$ ) shown in Supplementary Figure S1 were applied for each condition. The blue arrows indicate the direction of the decreasing concentration of NAA and BAP. Explants with roots are highlighted with a red square. 
(a)
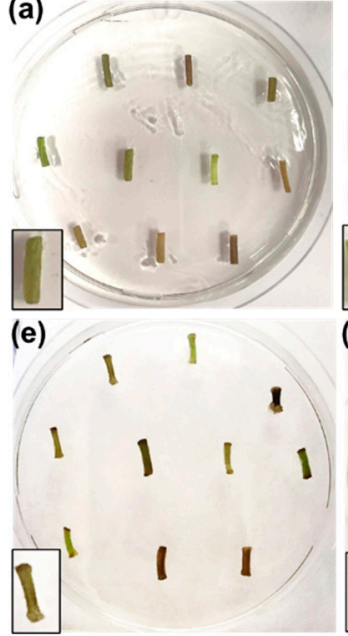

(b)

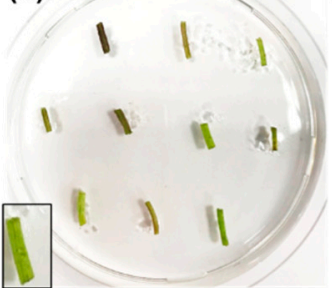

(f) (c)

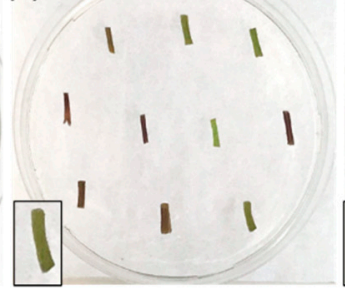

(g) (d)

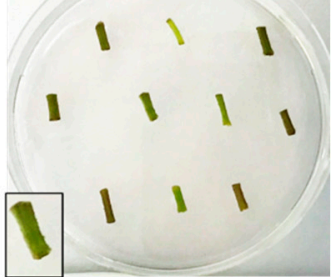

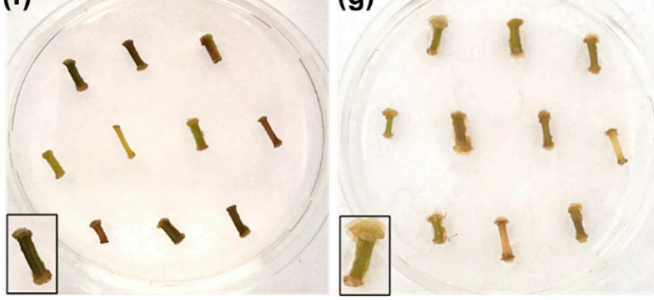

Figure 2. Pictures showing the effects of $3 \mathrm{mg} / \mathrm{L}$ NAA and $0.01 \mathrm{mg} / \mathrm{L}$ BAP on callogenesis of nettle explants at days 0 (a), 1 (b), 3 (c), 6 (d), 10 (e), 20 (f) and 34 (g) in the dark. Insets: details on the morphology of the internode explants at different time points.

\subsection{Selection of the Most Representative Time-Points of Nettle Callogenesis via qPCR}

A targeted gene expression analysis was performed via GPCR with the goal of identifying the most representative time-points during callogenesis in nettle. The medium used for callogenesis contained a high concentration of auxin (NAA at $3 \mathrm{mg} / \mathrm{L}$ ) and a lower concentration of cytokinin (BAP at $0.01 \mathrm{mg} / \mathrm{L}$ ); therefore, primers were designed on a set of genes involved in auxin signaling and transport, as well as cytokinin response. Fifteen genes involved in the metabolism of plant hormones (auxin and cytokinin) and cell cycle were chosen (Table 1), as their expression pattern provides important information on the dynamics of crucial pathways governing plant tissue trans-differentiation.

The genes chosen code for the orthologs of thale cress auxin influx carrier AUX1 [19,20]; the histidine phosphotransfer proteins AHP4-5 (positive regulators of cytokinin signaling [21]); the Arabidopsis response regulator (ARR12) protein (also acting in the cytokinin signaling pathway [22]), ARF19, -19-1 and -2B, which are members of the AUXIN RESPONSE FACTOR family [23]; the auxin-responsive proteins IAA21 and IAA22 [24]; the PINFORMED auxin efflux carriers located at the plasma membrane, PIN1a and PIN4 [25], and at the endoplasmic reticulum, PIN8 and PIN-LIKES7 (PILS7) [26,27]; and the cyclin D-type proteins CYCD3 and CYCD3.1 (responding to cytokinins and brassinosteroids [28]).

Table 1. Details of the genes and qPCR primers used in this study with indication of the sequence reference (contig/scaffold number relative to the previously published de novo assembly [9], or to the scaffold number from the onekp database [29,30]), respective gene names and amplification efficiencies (\%).

\begin{tabular}{|c|c|c|c|c|}
\hline $\begin{array}{l}\text { Sequence } \\
\text { Reference }\end{array}$ & Gene & Forward Primer $\left(5^{\prime} \rightarrow 3^{\prime}\right)$ & Reverse Primer $\left(5^{\prime} \rightarrow 3^{\prime}\right)$ & Efficiency \% \\
\hline contig_19482 & AHP4 & TTCGTGGAGGAAATCGCTAC & CTTTCAGCTGGTGCATGAAG & 109.9 \\
\hline WKCY_scaffold_2048943 & AHP5 & CGAGGCTCAGAATTTGGAAG & GCTCAAGCATGAACAGTTGG & 99.6 \\
\hline contig_1005 & $A R F 2 B$ & ATGAGGGCGATATGATGCTC & GTCTCCATGCGAATTTAGGG & 100.3 \\
\hline contig_3166 & ARF19 & CTGAAGCGTCATCTGAGCATAC & CGTCCATGAACATGAACACC & 90.6 \\
\hline WKCY_scaffold_2007870 & ARF19-1 & TTGCATGCCGATACAGAGAC & AAAACTCGGTGGGTTGTCTG & 101.3 \\
\hline contig_1723 & ARR12 & TGCTCTTCGTCCTCTTTTCC & ATGGGTTTCATCGCAGTCTC & 97.3 \\
\hline contig_2471 & AUX1 & CGAATGCCCAATACACACAG & GAGATTATGCACGCGATGTG & 92.0 \\
\hline contig_3855 & IAA22 & TTTTGGTGGCCGAAGTAGTC & CTCCGTGTTCAAGCATTTCC & 100.5 \\
\hline contig_15219 & $I A A 21$ & TCGTTCTCCTGAACATGCTG & TGTCCACCTCCCTTTTTCAG & 89.5 \\
\hline WKCY_scaffold_2013249 & CYCD3 & TTGCACTGGGAGTTTCTGTG & TGATCACGAGGAGCATTGTC & 94.7 \\
\hline contig_ 25826 & CYCD3.1 & TCTTGCTGGAACAAGACCTG & ATGCTCTTCGTCTTCCTTGG & 92.1 \\
\hline contig_20694 & PIN8 & CAGGCTGTGATGCGTAATTC & GAACCAGCAATGTTCGATCC & 97.2 \\
\hline contig_29151/WKCY_scaffold_2010532 & PIN1a & TGGGATGGCCATGTTTAGTC & AAACAACGCCACTGAGTTCC & 95.2 \\
\hline contig_8278 & PIN4 & TCTCCAGAAGCTCATCATGC & TGGAGAGGGAGAAGATGGTG & 95.8 \\
\hline contig_5072 & PILS7 & ACGCTGTTTGAAGTGGCATC & CGAAGTTGCCAAGAAAGCTC & 99.7 \\
\hline
\end{tabular}


The expression analysis showed major changes at the time-points $0,1,10$ and 34 days (Figure 3). Indeed, as can be seen in Figure 3, the expression patterns can be divided into three major trends: genes drastically decreasing in expression already at day 1 (namely, $A U X 1, A H P 4$ and -5, ARR12, ARF19-1 and -2B, and PIN4), increasing with the progression of trans-differentiation (ARF19, IAA21, IAA22, PIN1a and PILS7), or transcripts that do not show major changes during the kinetics (PIN8, CYCD3 and CYCD3.1). As expected, the genes showing the most dramatic response already after 1 day were those coding for the auxin influx carrier AUX1 and the auxin response factors ARF19-1 and -2B, as well as the histidine phosphotransfer proteins AHP4 and -5. However, it should be noted that ARF19 showed a different trend, since it progressively increased in expression over time. Additionally, the gene coding for the cytokinin-responsive transcription factor ARR12 showed an initial repression at 1 day, followed by an increase as callogenesis progressed. PIN1a, which is a member of the PIN-FORMED family controlling lateral root emergence [31], and PILS7, a gene controlling auxin signaling [27], increased in expression over time. This finding confirms the similarity existing between the genetic program underlying callogenesis and lateral root formation [16,32]. However, no major variations over time were observed for PIN8; an explanation could be ascribed to this gene having a role in processes other than callogenesis in nettle, for example, male gametophyte development, as demonstrated in thale cress [26]. The AUX/IAA genes targeted were progressively induced over time, similarly to what previously shown in thale cress organs undergoing callogenesis using a microarray analysis [32].

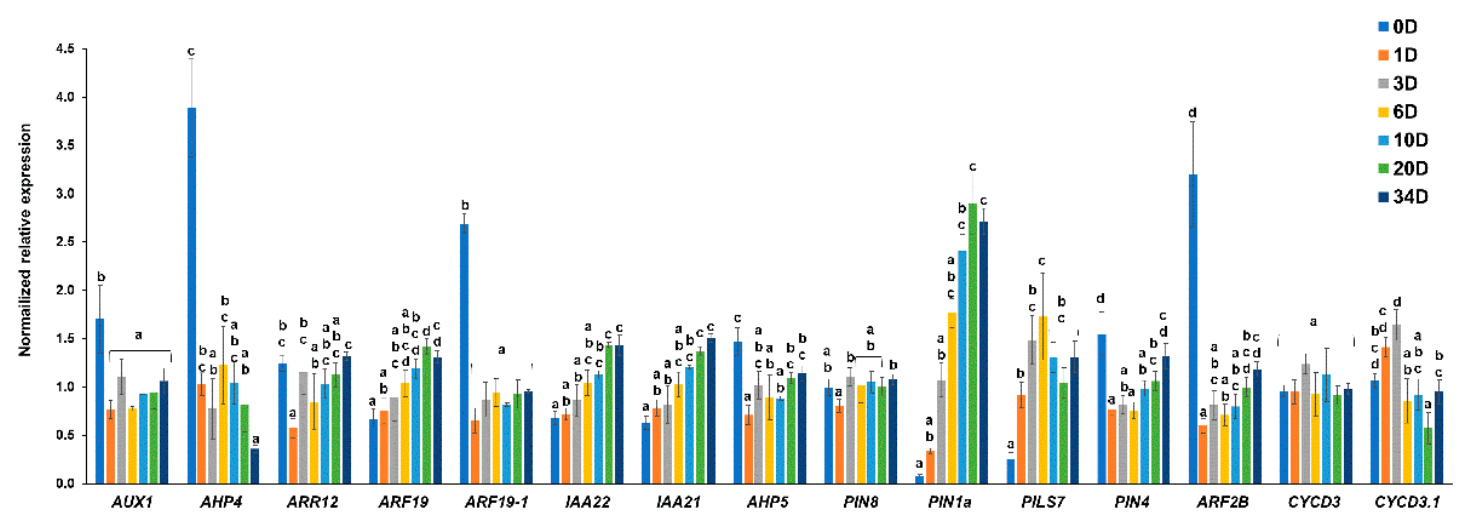

Figure 3. Expression analysis of a set of genes involved in hormone metabolism and cell cycle during callogenesis in nettle explants at $0,1,3,6,10,20$ and 34 days in the dark. Different letters denote statistical significance among groups obtained via the one-way ANOVA analysis with Tukey's post hoc test or via the Kruskall-Wallis test with Dunn's post hoc analysis $(p$-value $\leq 0.05)$. AUX1 $(\mathrm{F}(6,14)=10.80, p$-value $=0.000)$, PIN8 $(\mathrm{F}(6,14)=3.10, p$-value $=0.038)$, PILS7 $(\mathrm{F}(6,14)=37.98$, $p$-value $=0.000)$, PIN4 $(\mathrm{F}(6,14)=28.01, p$-value $=0.000), \operatorname{CYCD} 3.1(\mathrm{~F}(6,14)=12.10, p$-value $=0.000), A H P 4\left(X^{2}(6)=14.64\right.$, $p$-value $=0.022), A R R 12\left(X^{2}(6)=13.85, p\right.$-value $\left.=0.031\right), A R F 19\left(X^{2}(6)=17.47, p\right.$-value $\left.=0.008\right), A R F 19-1\left(X^{2}(6)=12.58\right.$, $p$-value $=0.050), I A A 22\left(X^{2}(6)=18.04, p\right.$-value $\left.=0.006\right), I A A 21\left(X^{2}(6)=18.42, p\right.$-value $\left.=0.005\right), A H P 5\left(X^{2}(6)=15.37\right.$, $p$-value $=0.018), P I N 1 a\left(X^{2}(6)=19.32, p\right.$-value $\left.=0.004\right), A R F 2 B\left(X^{2}(6)=17.42, p\right.$-value $\left.=0.008\right)$ and $C Y C D 3\left(X^{2}(6)=7.67\right.$, $p$-value $=0.263)$.

From the results obtained with qPCR, the time-points reflecting major transcriptional changes of plant hormone-related genes were $0,1,10$ and 34 days; indeed, these provided representative information about the progressive increase observed for ARF19, IAA21, $I A A 22$ and PIN1 $a$ and the early decrease characterizing the cytokinin-responsive transcript AHP4. Thus, for the subsequent RNA-Seq analysis, these time-points were considered.

\subsection{Gene Ontology Categories Characterizing Callogenesis at Different Time Points in Nettle}

RNA-Seq data were analyzed with a principal component analysis (PCA) and by performing a hierarchical clustering $(\mathrm{HC})$ of the gene expression data (represented as a heatmap, whereby the intensities of the pixels are proportional to the expression values) with the purpose of identifying major gene expression trends (Figure 4). The PCA 
highlighted a clear separation between day 0 (0D), 1 (1D) and 10/34 (10D/34D); the two latter time-points clustered indeed closely together (Figure 4a). A pathway analysis on the principal components (PCs) showed that processes related to the generation of precursors/energy, photosynthesis, cell wall polysaccharides and protein-containing subunit organization/assembly characterized PC1 with significant e-values, while PC2 comprised processes related to defense response, the response to external stimuli/stress, wounding and secondary metabolism (Table 2).

Table 2. Pathway analysis on PC1 and PC2 of the PCA shown in Figure 4a. The e-values of each pathway are indicated.

\begin{tabular}{|c|c|c|}
\hline Component & Pathways & e-Value \\
\hline \multirow{6}{*}{ PC1 } & Generation of precursor metabolites and energy & $1 \times 10^{-2}$ \\
\hline & Cell wall polysaccharide metabolic process & $5 \times 10^{-2}$ \\
\hline & Photosynthesis & $2 \times 10^{-12}$ \\
\hline & Photosynthesis, light reaction & $1 \times 10^{-5}$ \\
\hline & Protein-containing complex subunit organization & $2 \times 10^{-2}$ \\
\hline & Protein-containing complex assembly & $2 \times 10^{-2}$ \\
\hline \multirow{6}{*}{ PC2 } & Regulation of response to biotic stimulus & $5 \times 10^{-3}$ \\
\hline & Defense reponse & $8 \times 10^{-3}$ \\
\hline & Response to wounding & $5 \times 10^{-3}$ \\
\hline & Secondary metabolic process & $9 \times 10^{-3}$ \\
\hline & Regulation of response to external stimulus & $2 \times 10^{-3}$ \\
\hline & Regulation of response to stress & $8 \times 10^{-3}$ \\
\hline
\end{tabular}

The HC analysis revealed the presence of seven clear expression patterns when a Pearson correlation coefficient $>0.48$ was selected (Figure $4 \mathrm{~b}$ ). The rescaled expression profiles of each cluster are provided in Figure $4 \mathrm{c}$ and are referred to as C1-C7.

$\mathrm{C} 1$ is characterized by genes that peaked in expression at 34D; $\mathrm{C} 2$ and $\mathrm{C} 3$ group transcripts with higher expression at 10D; genes belonging to $\mathrm{C} 4$ and $\mathrm{C} 5$ increased in expression at 1D, then decreased; C6 and C7 comprise genes expressed at the highest level at $0 \mathrm{D}$.

A gene ontology enrichment (GOE) analysis was performed to obtain an overview of the major ontologies characterizing each of the seven clusters (Dataset S1).

Hereafter, the results are presented and discussed according to the trends highlighted by the clusters. 
(a)

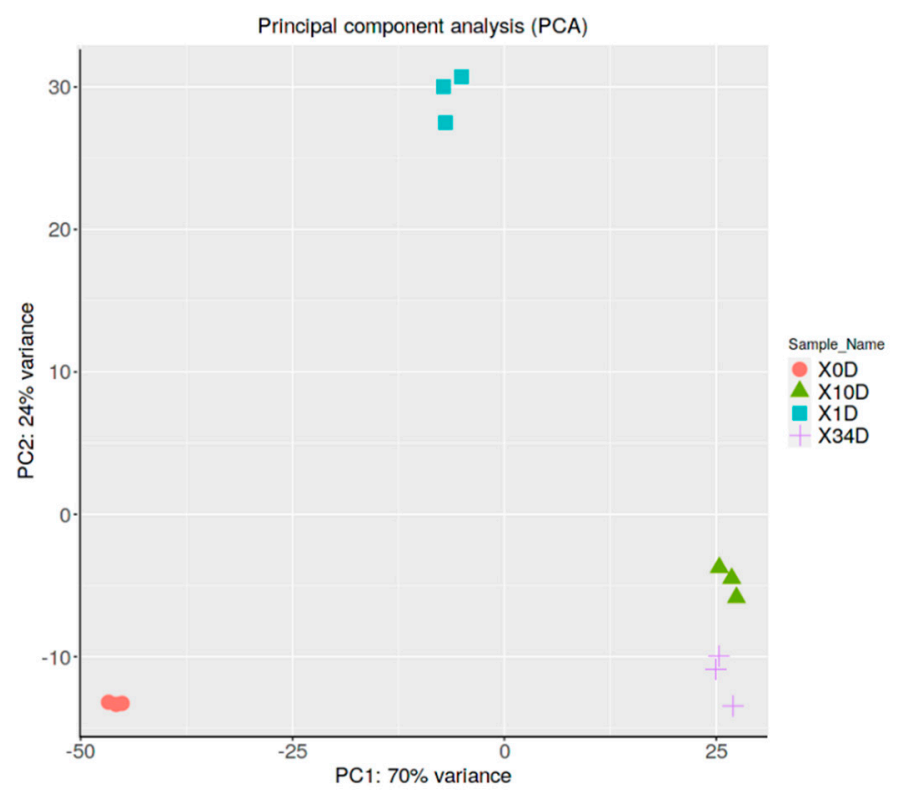

(b)

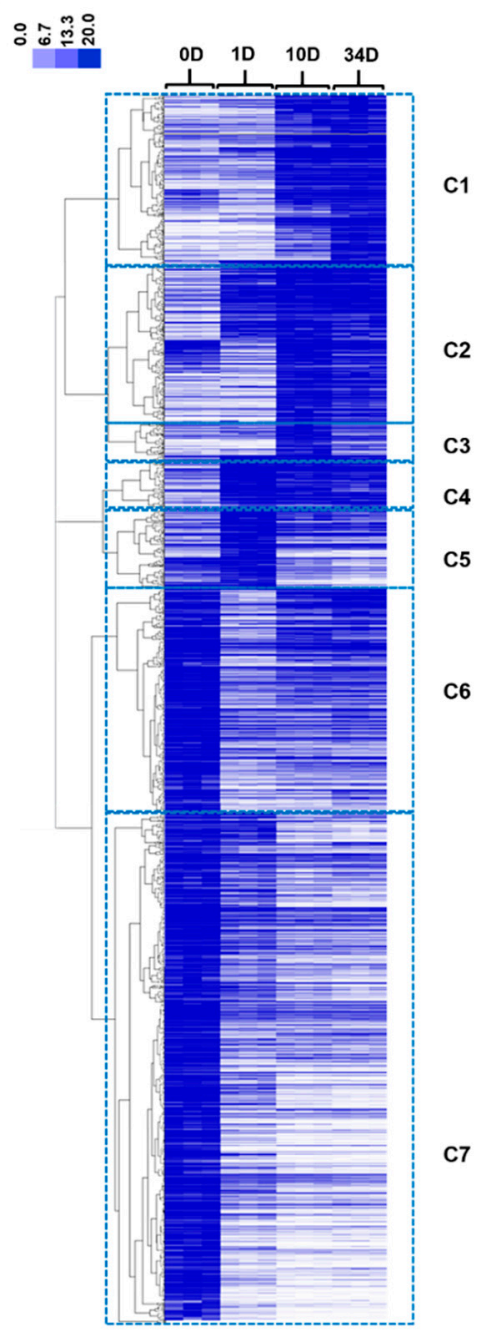

(c)

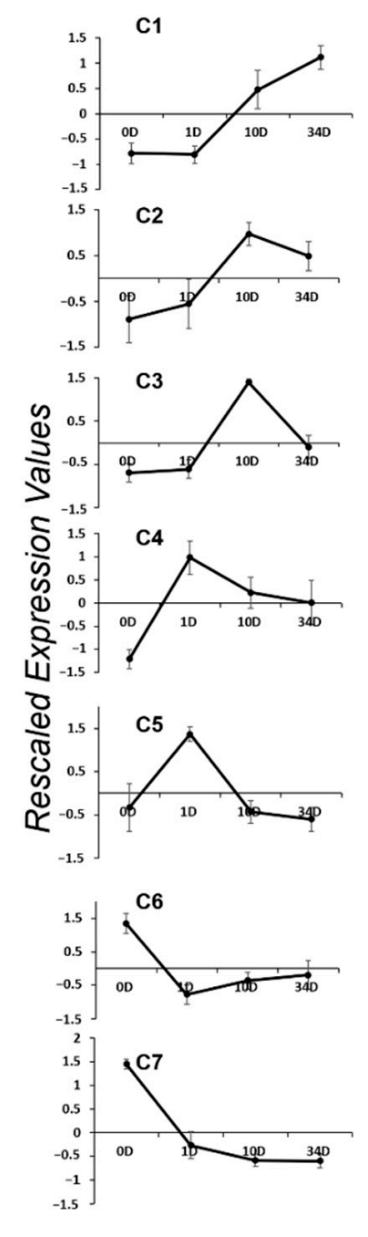

Figure 4. Principal component analysis (PCA) and heatmap of hierarchical clustering with major gene expression profiles. PCA of the RNA-Seq data (a). Heatmap of hierarchical clustering of the RNA-Seq 
data (b). C1-C7 clusters obtained using a Pearson correlation coefficient $>0.48$ (c). The scale bar indicates the expression intensities. (c) Profiles of the seven clusters of genes obtained using a Pearson coefficient $>0.48$. The profiles are relative to the $\log 2 \mathrm{RPKM}$ rescaled values \pm standard deviation (the rescaled values were obtained by subtracting, to the expression value of each contig, the average among the three biological replicates and dividing by the standard deviation).

\subsubsection{Ontologies Characterizing the Advanced Stage of Callogenesis (Cluster C1)}

Iron Deficiency Response

The GOE analysis revealed the presence of ontologies related to the response to reactive oxygen species (ROS) and glutathione metabolic processes (Dataset S1). In the first category, three genes were found: two genes encoding 2-oxoglutarate and ferrous iron $\mathrm{Fe}^{2+}$-dependent dioxygenases (contig_3159 and contig_2278, orthologs of At3g12900 and At3g13610) and an alpha dioxygenase (contig_5174, ortholog of DOX1-At3g01420). These genes all showed a $\log 2 \mathrm{FC}>3$, when comparing the expression values at $0 \mathrm{D}$ vs. $34 \mathrm{D}$, and are highly up-regulated at the last point of the kinetics. In particular, At3g12900 codes for a scopoletin 8-hydroxylase $(\mathrm{S} 8 \mathrm{H})$ which is involved in the biosynthesis of fraxetin from scopoletin, two coumarins playing a role in strategy I iron uptake in dicots such as thale cress $[33,34]$. Strategy I relies on the reduction mechanism mediated by the release of protons in the rhizosphere which acidify and increase the solubility of iron in the soil [35].

Together with these genes, an induction of the nettle orthologs of COSY-At1g28680 (contig_153) and CYP82C4-At4g31940 (contig_12259) was also observed (log2FC at $0 \mathrm{D}$ vs. $34 \mathrm{D}=1.35$ and 1.99 , respectively; Dataset $\mathrm{S} 1$ ), a finding pointing to the presence of the complete pathway leading from feruloyl-CoA to sideretin. Here, it is also worth highlighting that the nettle ortholog of the ABC transporter ABCG37/PDR9-At3g53480 (contig_9754) involved in the secretion of scopoletin and derivatives [36] was slightly induced at $34 \mathrm{D}$ (the gene is grouped in $\mathrm{C} 6$ though), with an $\mathrm{FC}=1.6$, when comparing $34 \mathrm{D}$ vs. $0 \mathrm{D}$ (Dataset $\mathrm{S} 1)$.

COSY, a member of the BAHD acyltransferases, is responsible for lowering the activation energy needed to convert trans-O-hydroxycinnamoyl-CoA thioesters to cis-Ohydroxycinnamoyl-CoA thioesters [37], while CYP82C4 is a cytochrome P450 (CYP) involved in the oxidation of fraxetin to sideretin [34]. CYP82C4, together with two additional CYPs, CYP71B5 and CYP82C3, is induced upon the so-called "iron deficiency response" and it is the only gene correlating with transcripts involved in metal uptake/transport in thale cress [38]. In the RNA-Seq dataset here produced, genes coding for iron transporters were not identified, which, however, does not exclude the possibility that they are up-regulated during callogenesis, given the de novo nature of the transcriptome used as reference [9]. In support of the involvement of the iron deficiency response in nettle explants undergoing callogenesis is the up-regulation of a lysyl-tRNA synthetase (contig_30661), ortholog of AtKRS-1 (At3g11710), and of a gene annotated as B12D (contig_526), which are among the genes in $\mathrm{C} 1$ showing the highest FC difference between $34 \mathrm{D}$ and 0D (Dataset S1). The stable expression of the thale cress lysyl-tRNA synthetase in maize triggers translational recoding of lysine into zeins, thereby enriching the lysine content of grains [39]; additionally, AtKRS-1 is up-regulated in A. thaliana under iron deficiency [40]. It was proposed that this gene is involved in the adaptation of plants to stress by promoting translational recoding [39]. In the tomato chloronerva mutant, characterized by high apoplastic and symplastic iron concentrations but showing an iron-deficient behaviour, a root-specific lysyl-tRNA synthetase was shown to be up-regulated and to depend on iron availability [41]. Besides its role in protein biosynthesis, plant lysyl-tRNA synthetases may be involved in the synthesis of adenylated $5^{\prime}$-nucleosidyl tetraphosphates (AP4Ns), analogously to what described in Escherichia coli [42]. AP4Ns were shown to accumulate in stressed prokaryotic and eukaryotic cells $[43,44]$ and their production in stressed plant cells suggests that they may function as "alarmones" [41,45] (i.e., intracellular signals affecting duplication and gene expression under harsh environmental conditions [46]). 
The gene $B 12 D$ codes for an NADH-ubiquinone reductase complex 1 MLRQ subunit and, in rice, its expression was induced upon anoxia, submergence and flooding [47], as well as iron deficiency [48]. This last result corroborates, once more, the presence of the iron deficiency response during nettle callogenesis; the higher expression of nettle $B 12 D$ may be linked to the production of ATP and, hence, to adaptation under high iron requirements (mimicking an iron deficiency syndrome).

Among the transcription factors (TFs) linked to the biosynthesis of coumarins and iron deficiency, it is important to mention bHLH115 (At1g51070) and WRKY72 (At5g15130); the nettle orthologs of these genes (contig_9857 for bHLH115; contig_726 and contig_1302 for WRKY72) both clustered in $\mathrm{C} 1$ and showed a $\log 2 \mathrm{FC} 34 \mathrm{D}$ vs. $0 \mathrm{D}>2$ and $>6$, respectively (Dataset S1). The TF bHLH115 is up-regulated in the pericycle upon iron deficiency and interacts with another bHLH, POPEYE, by forming a heterodimer which, in turn, binds BRUTUS, a putative E3 ligase protein functioning as a repressor and coordinating iron homeostasis [49]. WRKY72 was identified as a putative QTL (quantitative trait locus) affecting scopoletin biosynthesis in A. thaliana recombinant inbred line populations [50].

\section{Scavenging of ROS}

Iron deficiency causes an accumulation of other metals, for example, zinc [51], due to the increased activity of ferric-chelate reductase which can accept other metals [41]. An over-accumulation of metals causes, in turn, an increase in ROS production in plant cells and the subsequent need to scavenge them; thus, the lysyl-tRNA synthetase can work in a context of anti-oxidative response. However, what seems a more plausible explanation for the iron deficiency response observed in the present experimental context is the induction of ROS due to tissue trans-differentiation to callus, more than the over-accumulation of other metals; ROS are known to mediate several important physiological responses and developmental stages in plants, among which the maintenance of vegetative apical meristems. The accumulation of ROS leads to the need to scavenge them via antioxidant enzymes, some of which require indeed iron as co-factor (superoxide dismutase, catalase and ascorbate peroxidase [52]). The balance between $\mathrm{H}_{2} \mathrm{O}_{2}$ and $\mathrm{O}_{2} \bullet-$ is, for example, known to be crucial in the root meristem to mark the shift from proliferation to elongation; ROS homeostasis and distribution are regulated via the bHLH transcription factor UPBEAT1-UPB1, which determines the boundaries of the transition zone by negatively regulating peroxidases, thus affecting the concentration of $\mathrm{H}_{2} \mathrm{O}_{2}$ [53]. $\mathrm{H}_{2} \mathrm{O}_{2}$ is scavenged by peroxidases, enzymes known to affect cell wall-related processes in plants by acting in either stiffening or loosening [54]. In the root meristem, their increased activity marks the onset of differentiation. In the experimental dataset here obtained, UPB1 clustered in C4, together with transcripts highly induced at 1D (Dataset S1). Its expression then decreased, but, at 34D, it was still four-fold higher than that at $0 \mathrm{D}$, a finding indicating that trans-differentiation in nettle is accompanied by mechanisms regulating ROS levels. It remains to be proven whether nettle callogenesis is characterized by a fast increase in $\mathrm{H}_{2} \mathrm{O}_{2}$ levels coinciding with the observed strong up-regulation of $U P B 1$ at very early stages of trans-differentiation.

Three members of the tau-class of glutathione $S$-transferases [55] were up-regulated in C1, namely, GSTU7, $-8(\log 2 \mathrm{FC} 34 \mathrm{D}$ vs. $0 \mathrm{D}>6)$ and $-9(\log 2 \mathrm{FC} 34 \mathrm{D}$ vs. $0 \mathrm{D}>1.4$; Dataset S1), a finding confirming the need to activate the antioxidant system in the cells undergoing callogenesis. GSTU7 from thale cress (corresponding to nettle contig_10747 and contig_3454) was shown to antagonize the oxidative stress caused by methyl viologen [56], while GSTU9 (contig_7301 and contig_4735) was up-regulated in Arabidopsis overexpressing a plastidial glycolate oxidase (where $\mathrm{H}_{2} \mathrm{O}_{2}$ is produced in chloroplasts) [57]. Among the TFs induced in $\mathrm{C} 1$, it is worth mentioning TGA2 (contig_10732, log2FC 34D vs. $0 \mathrm{D}=1.07$ ), which mediates the response to UV-B and methyl viologen-triggered ROS and induces GSTU7, -8 and -25 expression by binding to their promoters [58]. The observed induction of GSTU genes in nettle at 34D of callogenesis confirms the involvement of ROS in transdifferentiation to callus. 
Pathogenesis-Related Transcripts

Genes coding for pathogenesis-related proteins (contig_2102, contig_16024 and contig_8710), proteinase inhibitor (contig_2377 and contig_6693), thaumatin-like protein 1 (contig_15054) and an acetone-cyanohydrin lyase (contig_17332) were all induced at $34 \mathrm{D}$ (minimum calculated $\log 2 \mathrm{FC} 34 \mathrm{D}$ vs. $0 \mathrm{D}>1.5$ ). This is in agreement with what previously shown for thale cress pluripotent calli, where RNA-Seq revealed the induction of several transcripts involved in the response to biotic stress, thus the presence of defense systems against microbial invaders in trans-differentiated cells [59]. The high induction of the acetone-cyanohydrin lyase (also known as hydroxynitrilase) suggests an enzymatic route leading to the liberation of hydrogen cyanide $(\mathrm{HCN})$ from cyanogenic glycosides. These compounds are known to act as "phytoanticipins" (i.e., plant defense compounds acting against biotic agents) [60]; however, a study also suggested that HCN may impact the endogenous levels of ROS and contribute to release dormancy in sunflower seeds [61]. Hence, a signaling pathway linking HCN and ROS homeostasis may exist in nettle calli.

2.3.2. Ontologies Characterizing the Intermediate Stage of Callogenesis (Clusters C2-C3) Immune Response

The GOE analysis of clusters $\mathrm{C} 2$ and $\mathrm{C} 3$ revealed the presence of transcripts related to the phenylpropanoid pathway, the immune/defense response, salicylic acid (SA) and hypoxia response, and auxin transport (Dataset S1). Among the transcripts linked to the immune response and showing increased expression at 10D, the TF ERF2 (contig_3897, $\log 2 \mathrm{FC} 10 \mathrm{D}$ vs. $0 \mathrm{D}>1.5$ ), which is induced by SA [62], and two genes encoding calmodulinbinding proteins ( $\log 2 \mathrm{FC} 10 \mathrm{D}$ vs. $0 \mathrm{D}>2.6$ ), namely, CBP60A (At5g62570, corresponding to contig_9925) and CBP60G (contig_10118), were found (Dataset S1). This last gene is a master regulator of immune defense response together with SARD1 [63], also upregulated in nettle explants at 10D (contig_3315; Dataset S1). SARD1 does not bind calmodulin, differently from CBP60G, but these TFs activate both the SA-dependent and independent immune response [63]. Both SARD1 and CBP60G can induce the expression of the TF WRKY70, whose ortholog in nettle almost doubled in expression at 10D compared to 0D (contig_10625; Dataset S1). WRKY70 is a check-point of the SA- and jasmonic acid (JA)related stress signals by repressing the latter and stimulating the former [64]. It also acts as either repressor or activator, depending on whether pathogens are present or not; indeed, this TF can bind to the SARD1 promoter (GACTTTT motif) and repress its expression in the absence of an infection [65].

Calcium- $\mathrm{Ca}^{2+}$ signaling is an important aspect of plant defense response. Upon treatment with damage-associated molecular patterns (DAMPs) such as oligogalacturonides, a rapid $\mathrm{Ca}^{2+}$ influx was observed in Nicotiana plumbaginifolia cell cultures and the use of chemicals blocking the influx failed to activate downstream targets, namely, mitogenactivated protein kinases (MAPK), resulting in the absence of gene activation and the hypersensitive response [66]. Calmodulin-binding proteins, such as those belonging to the CBP60 family, participate in $\mathrm{Ca}^{2+}$ signaling and, when induced upon pathogen attack or MAMPs (microbe-associated molecular patterns), can induce the production of SA and, ultimately, the activation of SA-responsive genes [67]. Among the members of CBP60s in thale cress, $\mathrm{CBP} 60 \mathrm{~A}$ acts as a repressor of the immune response and has a role in conditions where pathogens are not present. When the plant is not facing an infection, $C B P 60 A$ levels are high and those of $C B P 60 G-S A R D 1$ are low, while the reverse happens when a strong MAMP signal is detected [67]. In cluster C2, both CBP60A and CBP60G are present with the same expression trend peaking at 10D (Dataset S1); since no infection was present, the co-expression of both CBP60s may represent a mechanism to control the intensity of the immune response, likely by preventing a full activation, which could exert a negative impact on the proliferation of the callus. In support of the existence of a mechanism controlling immune response is the induction of MKK6 (At5g56580, contig_3282; Dataset S1), an MAPK preventing constitutive activation of immune responses together with MAPK4 
(At4g01370) [68]. The nettle ortholog of this gene (contig_3775) is present in cluster 6, but it showed an increased expression (FC > 2.5) at 10D compared to 1D (Dataset S1).

It is also worth mentioning contig_7513, that codes for the ortholog of the MAC perforin domain-containing NSL1 (At1g28380), as well as contig_3372 encoding the ortholog of NUDT7 (At4g12720). Nettle NSL1 doubled in expression at 10D compared to $\mathrm{OD}$ (Dataset S1); this gene represses MAMP-induced cell death that is triggered by the synthesis of antimicrobial compounds via the production of SA [69]. Nettle NUDT7 showed a $\log 2 \mathrm{FC} 10 \mathrm{D}$ vs. $0 \mathrm{D}=2.6$ (Dataset $\mathrm{S} 1$ ); in thale cress, this gene was reported to be a negative regulator of immune response preventing excessive stimulation [70]. Once again, a subtle mechanism regulating immune response via SA-stimulation and controlling its overstimulation exists in nettle explants undergoing callogenesis.

In the experimental set-up here used, rigorous axenic conditions were adopted; therefore, the SA-related transcripts detected are likely linked to an altered cell wall integrity (CWI) status. It is now well established and documented that alterations in the CWI trigger defense responses in plants [71]; receptors strategically located at the interface between cell wall and plasma membrane act as "sentinels" by binding to, e.g., cell wall fragments which act as DAMPs. Several genes related to cell wall modification are indeed present in C4 and $\mathrm{C} 5$ as discussed below, a result showing that strong cell wall modifications are induced during callogenesis in nettle explants. This justifies the stimulation of pathways related with SA and, more generally, with the immune response observed at 10D in the absence of an infection. The up-regulation of the wall-associated kinase WAK2 (contig_15778; Dataset S1) corroborates the hypothesis of alterations in the CWI; this receptor binds to pectins, is induced by SA [72] and is slightly up-regulated following pectin treatment in thale cress protoplasts [73].

Transcriptomics also enabled the identification of another pathway intervening with SA to stimulate the immune response, i.e., the biosynthesis of $N$-hydroxypipecolic acid (NHP). This amino acid derivative intervenes in systemic acquired resistance (SAR), i.e., the long-lasting protection against biotic stressors and its biosynthesis starts with the catalytic action of ALD1 [74] (encoded by At2g13810), whose nettle ortholog clusters in C3 and shows a $\log 2 \mathrm{FC} 10 \mathrm{D}$ vs. 0D $>4.5$ (contig_17559; Dataset S1). The ortholog of FMO1 (At1g19250, contig_21504) is found in the same cluster and was strongly induced at 10D (Dataset S1). The product of this gene is responsible for the conversion of Lpipecolic acid to NHP [75]. Hence, RNA-Seq indicates that both SA and NHP intervene during nettle callogenesis; in the future, it will be necessary to quantify the levels of these two compounds, to determine their kinetics of accumulation during the proliferation of the callus.

\section{Phenylpropanoid Pathway- and Hypoxia-Related Transcripts}

It should be noted that several genes intervening in the phenylpropanoid pathway were found in C2 (Dataset S1); orthologs of thale cress CAD1 and CAD3 (At1g72680 and At2g21890, corresponding to contig_1059 and contig_4205, respectively, with log2FC 10D vs. $0 \mathrm{D}>3.5)$, as well as PAL1 (At2g37040, contig_4482), which almost doubled in expression at $10 \mathrm{D}$ compared to $0 \mathrm{D}$, and two genes coding for dirigent-like proteins (contig_23372 and contig_12966, $\log 2 \mathrm{GC} 10 \mathrm{D}$ vs. 0D > 2.5) were found in the dataset. The phenylpropanoid pathway synthesizes secondary metabolites which play an important role in plant defense response [76].

The intermediate stage of nettle callogenesis is also characterized by the induction of genes related to the response to hypoxia; the nettle ortholog of HRA1 (At3g10040) was found in C2 (contig_5635) and showed a $\log 2 \mathrm{FC} 10 \mathrm{D}$ vs. $0 \mathrm{D}>8$, together with contig_1034, which is orthologous to HB1-At2g16060 and doubled in expression at 10D compared to 0D (Dataset S1). Pyruvate decarboxylase (contig_472, log2FC 10D vs. 1C > 3.5; Dataset S1), a fermentative enzyme activated upon low oxygen levels [77], was also found in C2. Hypoxia is triggered upon the rapid proliferation of cells typically occurring in the dividing cells of plant calli; the stimulation of cell division triggered by the PGRs auxin and 
cytokinin triggers an increased consumption of oxygen needed to support the enhanced metabolic demand of the proliferating cell mass, in a manner analogous to that observed in crown galls after Agrobacterium tumefaciens infection [78].

Transcripts Involved in the Metabolism of Brassinosteroids and Auxins

Ontologies related to lipid biosynthesis and, more specifically, to the metabolism of brassinosteroids (BRs) were also identified at the intermediate stage of callogenesis. The orthologs of MEE31 (At3g02570, contig_6483, log2FC 10D vs. OD = 1.1), BAS1 (At2g26710, contig_10801, log2FC 10D vs. 0D > 5), CYP716A1 (At5g36110, contig_5745, $\log 2 \mathrm{FC} 10 \mathrm{D}$ vs. $0 \mathrm{D}>2.5$ ) and CYP724A1 (At5g14400, contig_29844, log2FC10D vs. 0D =6) were upregulated at 10D (Dataset S1). The involvement of BR-related genes likely depends on an alteration in the circadian rhythm. Callogenesis was set up in complete darkness; therefore, the differential regulation observed in these genes may be due to the experimental condition chosen.

MEE31, also known as PMI1 (phosphomannose isomerase 1), displays diurnal variations in expression and, more specifically, is induced in the light, upon an increase in ascorbic acid levels; MEE31 was also shown to be responsible for ascorbic acid synthesis in thale cress from hexose phosphates via the D-Man/L-Gal pathway [79]. The other genes of the same pathway are also known to respond to the light-dark cycle; for example, $B A S 1$, encoding a cytochrome P450, showed a $\log 2 \mathrm{FC} 10 \mathrm{D}$ vs. $0 \mathrm{D}=5.1$ (Dataset S1) and is a BR catabolic gene catalyzing the hydroxylation of brassinolide to the inactive form 26-hydroxybrassinolide [80]. Thus, during callogenesis, genes involved in BR signaling intervene in the adaptation to the prolonged dark conditions of callogenesis and transcripts regulating the conversion of active forms of the PGR to inactive ones may play a role in keeping the right concentrations of active forms. However, this needs validation via quantification of BRs.

Auxin-related genes were also found in C2; ABCB4 (At2g47000, contig_9223), AGG2 (At3g22942, contig_12241) and ZIFL1 (At5g13750, contig_11950) all showed a log2FC10D vs. 0D > 2 (Dataset S1). As discussed above, in Section 2.2, auxin-related genes were expected to vary significantly in expression given the use of the PGR in the medium. An additional piece of information is provided by the expression pattern of AGG2; this gene acts by increasing the stability of NDL1, required for local auxin maxima and is induced by high auxin levels [81]. Here, it is relevant to mention that the expression of NDL1 decreased with callogenesis (the gene was found in C7) and that a feedback signaling mechanism controlling auxin transport and gradient via the action of AGG2-NDL1 exists in nettle explants during callogenesis.

2.3.3. Ontologies Characterizing the Early Stages of Callogenesis (Clusters C4, C5, C6 and C7)

\section{Transcripts Involved in Cell Wall Loosening}

The early stage of callogenesis (1D) is characterized by ontologies related with cell wall catabolic processes, cell wall loosening and metabolism of dicarboxylic acids and cytokinins (Dataset S1). Already $24 \mathrm{~h}$ after exposure of the explants to the PGRs, cell wall remodelingrelated processes were induced. Three members of the glycosyl hydrolase family $9 \mathrm{~B}$ (GH9B) were indeed found in C4, i.e., GH9B1-2-6-8 (At1g70710, At1g02800, At1g23210 and At2g32990, corresponding to contig_29909, contig_29728, contig_22184 and contig_19509, respectively, all with $\log 2 \mathrm{FC} 1 \mathrm{D}$ vs. $\mathrm{OD}>2$; Dataset $\mathrm{S} 1$ ). GH9s belong to the CAZY (Carbohydrate-Active enZYmes Database; http:/ / www.cazy.org/, accessed on 13 September 2021) family of inverting enzymes formerly known as cellulase family $E$ and grouping also endoglucanases; the enzymes belonging to this family have been classified into three groups, namely A, B and C, depending on whether they have a transmembrane domain, a signal peptide, or a signal peptide with a carbohydrate binding module CBM49 [82].

GH9B1 (also known as cel1) is expressed in expanding tissues of thale cress and accumulates particularly in xylem cells [83] and its knock-down triggers shorter stems 
and roots, as well as less lignified xylem and phloem cells [84]. The expansins identified, EXPA1, -4 and -8 (At1g69530, At2g39700 and At2g40610, corresponding to contig_33240/contig_20613/contig_34011/contig_32221, contig_9569 and contig_31689/contig_35761, all with a $\log 2 \mathrm{FC} 1 \mathrm{D}$ vs. OD > 1.8), as well as the genes involved in pectin catabolism (At3g07010, At4g13710, At5g63180 and At4g33220-PME44, corresponding to contig_29771, contig_28278, contig_11050 and contig_27620, all with a $0.4<\log 2 \mathrm{FC}$ 1D vs. $0 \mathrm{D}=4.5$ ) and MIOX4 (At4g26260, contig_5715 with log2FC 1D vs. OD > 3) (Dataset S1) indicate major cell wall remodeling processes accompanying nettle callus formation. The presence of auxin in the medium is responsible for the major transcriptional changes observed, since this PGR is known to induce cell wall loosening [85]. Auxin induces acid growth via activation of $\mathrm{H}^{+}$-ATPase proton pumps $[86,87]$ and the acidic $\mathrm{pH}$ stimulates the activity of expansins [88]. Expansins loosen the connections between cellulose microfibrils and non-cellulosic polysaccharides making the former slide apart, thereby favoring relaxation of the walls. The low $\mathrm{pH}$ also stimulates the activity of pectin-related genes, namely, pectin methylesterases (PMEs) which de-methylesterify homogalacturonans either in a block-wise or random manner, ultimately affecting the mechanical properties of the cell wall (reviewed in [89]). The induction of two PMEs, together with several pectin lyases in C4-C5 suggests the likely occurrence of random de-methylesterification; randomly demethylesterified pectins are substrates of polygalacturonases and pectin lyases (increasing cell wall loosening), while block-wise de-methylesterified pectins give rise to a gel via the interaction with $\mathrm{Ca}^{2+}[90]$.

Among the cell wall-related genes induced at 1D, it is worth mentioning MIOX4, coding for a myo-inositol oxygenase; this enzyme is implicated in the synthesis of cell wall nucleotide sugar precursors, more specifically UDP-GlcA (glucuronic acid), as an alternative pathway to the direct oxidation of UDP-glucose [91]. However, MIOX4 was also shown to be involved in ascorbic acid biosynthesis by means of over-expression studies [92], via the conversion to L-gulonate, although subsequent radiotracer experiments in Arabidopsis using a frame-shift mutant of glucuronokinase $1 \mathrm{did}$ not show any accumulation of labelled ascorbic acid [93]. It must be said that, in the present study, no unequivocal conclusions can be drawn as to whether MIOX4 is the preferred route for UDP-GlcA biosynthesis during the early stage of nettle callogenesis, since data on the differential expression of genes involved in the synthesis of myo-inositol are not present and the quantification of UDP-xylose, known to inhibit UDP-glucose dehydrogenase via a negative feed-back [94], was not performed.

Among the genes induced at 1D, three transcripts encoding DUF642 family proteins were found: contig_29087, contig_12994 and contig_21054 (Dataset S1). DUF642 proteins are generally related to changes in pectin methyl-esterase activity or changes to the degree of methyl-esterification of homogalacturonans [95]; for example, the DUF642 genes At4g32460 and At5g11420 had a positive effect on seed germination when overexpressed in thale cress, via promotion of PME activity and testa rupture [96] and At3g08030 was proposed as a marker of seed ageing, as its expression was positively correlated with seed germination [97].

\section{Transcripts Related with the Metabolism of Organic Acids and Cytokinins}

In the early phase of callogenesis, an induction of transcripts involved in the metabolism of dicarboxylic acids was also observed (Dataset S1). Organic acids such as malate and fumarate were shown to act as temporary C-storage in C3 plants, such as $A$. thaliana after a prolonged dark period, to sustain respiration after carbohydrate depletion [98]. The darkness imposed in the experimental set-up here chosen triggered clear and needed metabolic adjustments to support the metabolism under the prolonged absence of light.

A fine balance of active cytokinins, at least at the transcriptomic level, was also present during early callogenesis; three cytokinin metabolism-related genes, CKX1 and -6 (At2g41510 and At3g63440, corresponding to contig_13913 and contig_12745, both with a $\log 2 \mathrm{FC} 1 \mathrm{D}$ vs. $0 \mathrm{D}>2.5$ ) and LOG7 (At5g06300, corresponding to contig_32442, log2FC 1D 
vs. $0 \mathrm{D}=7.9$ ) were identified (Dataset S1). CKXs encode cytokinin oxidases [99] catalyzing the degradation of the PGR, while LOG7 codes for a cytokinin nucleoside-monophosphate phosphoribohydrolase releasing active cytokinins [100]. An increased expression of some CKXs was previously also observed in Arabidopsis explants cultivated on a callus-inducing medium containing kinetin [32], while LOG7 was up-regulated in wounded explants showing callus formation [17]. Therefore, the balanced action of exogenous and endogenous cytokinin triggered upon wounding of the stem internode explants likely coordinate the early phase of nettle callogenesis.

Transcripts Involved in Base Excision Repair, Cell Wall Biosynthesis and Photosynthesis

Several gene ontologies were found in nettle internode explants transferred on a callusinducing medium at the beginning of callogenesis (0D) and a comparison between the extreme time-points, i.e., 34D vs. 0D, revealed 259 transcripts up-regulated at 0D (Dataset S1).

Here, the results are discussed by focusing on three crucial pathways, given their documented role in the determination of plant cell fate [101,102] and because it would be too broad to treat in detail all the gene ontologies enriched at $0 \mathrm{D}$. Here, the focus is given to base excision repair- and cell wall-related processes, as well as photosynthesisrelated ontologies.

Base excision repair (BER) is a mechanism regulating genome defense by repairing lesions to DNA caused by genotoxic agents; it is also responsible for another important pathway, namely, the replacement of 5-methylcytosine with cytosine in active DNA demethylation [103]. Callogenesis requires changes in the chromatin structure of plant cells; it was indeed demonstrated that, during the leaf-to-callus transition in thale cress, changes in DNA methylation occurred, with CHG regions showing increased methylation and $\mathrm{CHH}$ demethylation [104]. Epigenetic reprogramming linked to chromatin configuration is involved in callogenesis; to erase leaf identity genes, trimethylation of histone 3 lysine 27 (H3K27me3) occurs during the leaf-to-callus transition [105].

In the present RNA-Seq dataset, three genes involved in BER were up-regulated at $0 \mathrm{D}(0.53 \leq \log 2 \mathrm{FC} 0 \mathrm{D}$ vs. $1 \mathrm{D} \leq 2.68$; Dataset $\mathrm{S} 1)$ and progressively down-regulated as callogenesis progressed-contig_31442 and contig_22351 (corresponding to the DNA glycosylases At3g12710 and At5g44680) and contig_22270 (corresponding to At2g36490-DML1, a DNA demethylase involved in Fusarium resistance in Arabidopsis [106]). The explants used for the present study derive from the stem and the observed down-regulation of genes involved in BER can be explained by the need to repress genes involved in establishing the identity of aerial organs and favor callogenesis.

Three genes involved in secondary cell wall biosynthesis, namely, IRX1, IRX3 and IRX12 (corresponding to contig_27738, contig_22306 and contig_31490, respectively) also showed a progressive down-regulation with the progress of callogenesis $(2.50 \leq \log 2 \mathrm{FC} \mathrm{0D}$ vs. $1 \mathrm{D} \leq 3.08$; Dataset $\mathrm{S} 1$ ). IRX1 and IRX3 code for two cellulose synthases involved in secondary cell wall biosynthesis, i.e., CESA8 and CESA7 [107]; their down-regulation accompanied the loosening observed at $1 \mathrm{D}$ and confirms the important contribution of cell walls to the identity of plant cells. For example, the modification or complete removal of the cell wall (to generate protoplasts) is known to be a component of in vitro transdifferentiation and pluripotency $[108,109]$.

Callogenesis was performed under dark conditions; thus, to observe a number of differentially regulated photosynthesis-related transcripts was expected. Among them, genes involved in chloroplast relocation showed a statistically significant down-regulation at $1 \mathrm{D}$ compared to 0D; phototropins (corresponding to contig_27228 and contig_14966), as well as the glutaredoxin family protein AT1G64500 involved in actin bundling and chloroplast movement (corresponding to contig_2269) displayed a log2FC 0D vs. 1D > 1.5 (Dataset S1). The changes triggered on the photosynthetic machinery accompany the switch to a heterotrophic metabolism, an alteration of the source/sink balance and the subsequent loss of photosynthetic capacity and re-entry into the cell cycle. Mechanically separated Asparagus 
cells showed a loss of photosynthetic capacity associated with the onset of the cell cycle and accompanying chloroplast trans-differentiation to proplastid-like structures [110].

\section{Materials and Methods}

\subsection{Plant Materials and Growth Conditions}

Terminal shoots containing several nodes were collected from healthy vigorous nettle plants (i.e., the fibre clone 13) growing in the incubators under a cycle of $16 \mathrm{~h}$ light at $25^{\circ} \mathrm{C}$ and $8 \mathrm{~h}$ dark at $20{ }^{\circ} \mathrm{C}$, as previously reported [111]. The shoots were first washed with detergent (i.e., water with a few drops of soap) for $10 \mathrm{~min}$, then submerged in $50 \%$ $(v / v)$ commercial bleach for $10 \mathrm{~min}$, followed by three rinses with sterilized distilled water. Segments bearing a single node of the surface-sterilized shoots were put vertically onto Murashige and Skoog (MS) basal medium containing vitamins (Duchefa Biochemie, Haarlem, The Netherlands), 3\% (w/v) sucrose and $0.8 \%(w / v)$ agar and grown in a culture room under light-emitting diode (LED) lights (Philips GreenPower LED production module DeepRed/Blue) with a $16 / 8 \mathrm{~h} \mathrm{light/dark} \mathrm{cycle} \mathrm{at} \mathrm{a} \mathrm{constant} \mathrm{temperature} \mathrm{of} 22{ }^{\circ} \mathrm{C}$. The obtained in vitro plantlets were sub-cultured by transferring terminal shoots to the same fresh media. The internode explants of $1 \mathrm{~cm}$ length were excised from 4 -week-old plantlets and used for the subsequent experiments.

\subsection{Optimal Concentrations and Combinations of Plant Growth Regulators for Callus Induction}

To determine the optimal concentration of BAP and NAA for callus induction, the combination of different concentrations was first examined using $100 \mathrm{~mm}$ square Petri dishes with $25(5 \times 5)$ compartments (Thermo Fisher Scientific, Bremen, Germany). Various concentrations of both BAP and NAA (3, 1, 0.5, 0.1 and $0.01 \mathrm{mg} / \mathrm{L})$ were used to obtain a total of 25 combinations (Supplementary Figure S1). These BAP-NAA combinations were added to the MS basal medium supplemented with vitamins, $0.1 \%(w / v) \mathrm{KNO}_{3}, 0.08 \%$ $(w / v) \mathrm{NH}_{4} \mathrm{NO}_{3}, 0.12 \%(w / v) \mathrm{KH}_{2} \mathrm{PO}_{4}, 1 \%(w / v)$ sucrose and $0.3 \%(w / v)$ Gelrite (Duchefa Biochemie, Haarlem, The Netherlands). The internode explants were placed horizontally onto the medium and cultured in the dark or under the same condition as in vitro plants (two Petri dishes per condition).

\subsection{Sampling, RNA Extraction, $q P C R$ and Statistics}

The internode explants were cultured on the medium supplemented with $3 \mathrm{mg} / \mathrm{L}$ of NAA and $0.01 \mathrm{mg} / \mathrm{L}$ of BAP in the dark and collected at $0,1,3,6,10,20$ and 34 days. Ten explants from the same plate were pooled to generate one biological replicate for each time point and three biological replicates were collected. Total RNA extraction was performed using the RNeasy Plant Mini kit (Qiagen, Leusden, The Netherlands) according to the manufacturer's instructions. RNA quantity was measured using a NanoDrop ND1000 spectrophotometer (Thermo Fisher Scientific, Villebon-sur-Yvette, France). RNA quality was assessed with a 2100 bioanalyzer (Agilent, Santa Clara, CA, USA). cDNA synthesis was carried out using one $\mu \mathrm{g}$ of total RNA and ProtoScript II RTase (NEB) according to the manufacturer's instructions. All primers were designed with the online program Primer3Plus (http:/ /www.bioinformatics.nl/cgi-bin/primer3plus/primer3plus. cgi/ (accessed on 26 July 2019) and primer efficiency was calculated using 5-fold serial dilutions of cDNA ranging from $0.0008 \mathrm{ng} / \mu \mathrm{L}$ to $12.5 \mathrm{ng} / \mu \mathrm{L}$. Target genes were identified by blasting thale cress orthologs in the nettle leaf database at Blast4OneKP (available online at http:// db.cngb.org/blast4onekp/home (accessed on 26 July 2019); [29,30]). Primer sequences and amplification efficiencies are provided in Table 1. Five reference genes reported previously [111] were used in this study. Of these five, two reference genes (i.e., RAN and eTIF4E) were selected to calculate the relative gene expression, as they were determined to be the most stable by geNorm implemented in the qbase+ software v3.2 (Biogazelle, Zwijnaarde, Belgium). The normality and homogeneity of the data were checked using a Shapiro-Wilk test and a Levene's test, respectively. A one-way ANOVA with a Tukey's post hoc test was used when parametric testing was possible, while 
a Kruskal-Wallis with Dunn's post hoc test was used when parametric test's conditions were not met. The statistical analyses were performed with IBM SPSS Statistics v20 (IBM SPSS, Chicago, IL, USA).

\subsection{Preparation of the Libraries, RNA-Seq Analysis and Validation with $q P C R$}

The SMARTER stranded RNA-Seq Kit was used to prepare twelve libraries (i.e., three biological replicates for samples collected at $0,1,10$ and 34 days) following the manufacturer's instructions (Takara Bio, Saint-Germain-en-Laye, France) and as previously described [9]. The libraries were pooled and sequenced to generate $75 \mathrm{bp}$ paired-end reads using an Illumina NextSeq500 instrument with the NextSeq500/550 Mid Output Kit v2.5 (150 cycles; Illumina, San Diego, CA, USA). Raw sequences were deposited in NCBI Gene Expression Omnibus (GEO) with the accession number GSE185155. The raw sequences were uploaded to CLC Genomics Workbench v. 11.0.1 (QIAGEN Aarhus A/S, Denmark). The sequences were treated as previously described [9]: sequences $>35 \mathrm{bps}$ were retained, the sequence quality score was, by default, 0.05 and the maximum number of ambiguities was set to 0 . Adaptor trimming was performed using the Illumina adaptor sequences, then a hard trim of 15 bps at the $5^{\prime}$ end and 3 bps at the $3^{\prime}$ end was additionally carried out, resulting in a final sequence average length of $57 \mathrm{bps}$. Mapping was performed against the previously published de novo transcriptome of nettle clone 13 [9] with the following parameters: maximum hit per read $=3$; similarity and length fraction $=0.95$; mismatch $/$ insertion/deletion cost $=3$. The expression values were calculated using the RPKM (reads per kilobase of transcript per million reads mapped) method [112]. An ANOVA one-way statistical test with four groups (0,1,10 and 34 days) was applied, each composed of 3 biological replicates; thereafter, a false discovery rate (FDR) correction was applied. Only those genes showing a corrected $p$-value $<0.05$ were retained for the bioinformatics analysis. The data were filtered by removing the genes showing a maximum value of the means $<1$ RPKM and a maximum FC $>|4|$. A total of 3143 contigs were obtained (Dataset S1). The Gene Ontology term enrichment (GOE) analysis was performed using Cytoscape v3.7.1 [113] with the ClueGO v2.3.2 plugin [114] ( $p$-value < 0.05; Benjamini-Hochberg enrichment, gene ontology from level 3 to level 8 ; kappa score $=0.4$ ). Principal component analysis (PCA) and PCA pathway analysis were carried out using iDEP.93 [115]. Gene expression patterns were hierarchically clustered using Cluster 3.0 [116] and plotted as a heatmap with Java Treeview [117] (available online at http:/ / jtreeview.sourceforge.net/ (accessed on 1 September 2020)).

For qPCR validation, the following contigs were chosen: contig_9978, contig_11349, contig_27738, contig_31490, contig_35897, contig_4597, contig_25850 and contig_7440. The primers used have been previously reported [9]. The expression values were calculated with qbase+ as described in Section 3.3 and the reference genes used were RAN and eTIF4E [111]. The log2 fold change (FC) of the NRQs (normalized relative quantities) and RPKM were plotted and the $\mathrm{R}^{2}$ calculated (Dataset $\mathrm{S} 1$ ).

\section{Conclusions}

The results obtained in this study provide a comprehensive view of the transcriptional changes accompanying callogenesis in nettle stem explants. Key gene ontologies dominate at the different time-points studied and several new findings have been provided. Among the new findings, there is the iron deficiency response at the advanced stage of callogenesis triggered by the ROS and the need to scavenge them via antioxidant enzymes relying on iron as a co-factor. The up-regulation of genes related to the immune response at the intermediate stage is likely caused by an altered cell wall status, as evidenced by the major changes observed in cellulose- and pectin-related processes. The RNA-Seq data here provided will be a useful resource for researches focusing on plant callogenesis and on nettle-related applications based on tissue culture and bioprocess engineering.

Supplementary Materials: The following are available online at https:/ /www.mdpi.com/article/10 $.3390 /$ ijms222212319/s1. 
Author Contributions: Conceptualization, X.X. and G.G.; methodology, X.X., S.L., R.B. and G.G.; validation, X.X., R.B. and G.G.; formal analysis, X.X., S.L., R.B. and G.G.; investigation, X.X. and G.G.; resources, G.G. and J.-F.H.; data curation, X.X., S.L., R.B. and G.G.; writing-original draft preparation, X.X. and G.G.; writing-review and editing, S.L., R.B. and J.-F.H.; project administration, G.G.; funding acquisition, G.G. All authors have read and agreed to the published version of the manuscript.

Funding: This research project was funded by The Fonds National de la Recherche, Luxembourg, grant number C16/SR/11289002, and the APC was funded by LIST.

Institutional Review Board Statement: Not applicable.

Informed Consent Statement: Not applicable.

Data Availability Statement: Raw FASTA files, as well as processed RNA-Seq data, were deposited in GEO (GSE185155). The processed RNA-Seq data are included in Dataset S1.

Conflicts of Interest: The authors declare no conflict of interest.

\section{References}

1. Fehér, A. Callus, Dedifferentiation, Totipotency, Somatic Embryogenesis: What These Terms Mean in the Era of Molecular Plant Biology? Front. Plant Sci. 2019, 10, 536. [CrossRef] [PubMed]

2. Florentin, A.; Damri, M.; Grafi, G. Stress Induces Plant Somatic Cells to Acquire Some Features of Stem Cells Accompanied by Selective Chromatin Reorganization. Dev. Dyn. 2013, 242, 1121-1133. [CrossRef] [PubMed]

3. Krasteva, G.; Georgiev, V.; Pavlov, A. Recent Applications of Plant Cell Culture Technology in Cosmetics and Foods. Eng. Life Sci. 2021, 21, 68-76. [CrossRef] [PubMed]

4. Eibl, R.; Meier, P.; Stutz, I.; Schildberger, D.; Hühn, T.; Eibl, D. Plant Cell Culture Technology in the Cosmetics and Food Industries: Current State and Future Trends. Appl. Microbiol. Biotechnol. 2018, 102, 8661-8675. [CrossRef]

5. Santos, R.B.; Abranches, R.; Fischer, R.; Sack, M.; Holland, T. Putting the Spotlight Back on Plant Suspension Cultures. Front. Plant Sci. 2016, 7, 297. [CrossRef] [PubMed]

6. Kregiel, D.; Pawlikowska, E.; Antolak, H. Urtica spp.: Ordinary Plants with Extraordinary Properties. Molecules 2018, 23, 1664. [CrossRef]

7. Bourgeois, C.; Leclerc, É.A.; Corbin, C.; Doussot, J.; Serrano, V.; Vanier, J.-R.; Seigneuret, J.-M.; Auguin, D.; Pichon, C.; Lainé, É.; et al. Nettle (Urtica dioica L.) as a Source of Antioxidant and Anti-Aging Phytochemicals for Cosmetic Applications. Comptes Rendus Chim. 2016, 19, 1090-1100. [CrossRef]

8. Xu, X.; Guignard, C.; Renaut, J.; Hausman, J.-F.; Gatti, E.; Predieri, S.; Guerriero, G. Insights into Lignan Composition and Biosynthesis in Stinging Nettle (Urtica dioica L.). Molecules 2019, 24, 3863. [CrossRef]

9. Xu, X.; Backes, A.; Legay, S.; Berni, R.; Faleri, C.; Gatti, E.; Hausman, J.-F.; Cai, G.; Guerriero, G. Cell Wall Composition and Transcriptomics in Stem Tissues of Stinging Nettle (Urtica dioica L.): Spotlight on a Neglected Fibre Crop. Plant Direct 2019, 3 , e00151. [CrossRef]

10. Behr, M.; Faleri, C.; Hausman, J.-F.; Planchon, S.; Renaut, J.; Cai, G.; Guerriero, G. Distribution of Cell-Wall Polysaccharides and Proteins during Growth of the Hemp Hypocotyl. Planta 2019, 250, 1539-1556. [CrossRef]

11. Suryawan, I.G.P.A.; Suardana, N.P.G.; Winaya, I.N.S.; Suyasa, I.W.B.; Nindhia, T.G.T. Study of Stinging Nettle (Urtica dioica L.) Fibers Reinforced Green Composite Materials: A Review. IOP Conf. Ser. Mater. Sci. Eng. 2017, 201, 012001. [CrossRef]

12. Suomela, J.A.; Vajanto, K.; Räisänen, R. Seeking Nettle Textiles-Utilizing a Combination of Microscopic Methods for Fibre Identification. Stud. Conserv. 2018, 63, 412-422. [CrossRef]

13. Shah, S.S.; Qasem, M.A.A.; Berni, R.; Del Casino, C.; Cai, G.; Contal, S.; Ahmad, I.; Siddiqui, K.S.; Gatti, E.; Predieri, S.; et al. Physico-Chemical Properties and Toxicological Effects on Plant and Algal Models of Carbon Nanosheets from a Nettle Fibre Clone. Sci. Rep. 2021, 11, 6945. [CrossRef]

14. Guerriero, G.; Berni, R.; Muñoz-Sanchez, J.A.; Apone, F.; Abdel-Salam, E.M.; Qahtan, A.A.; Alatar, A.A.; Cantini, C.; Cai, G.; Hausman, J.-F.; et al. Production of Plant Secondary Metabolites: Examples, Tips and Suggestions for Biotechnologists. Genes 2018, 9, 309. [CrossRef]

15. Atta, R.; Laurens, L.; Boucheron-Dubuisson, E.; Guivarc'h, A.; Carnero, E.; Giraudat-Pautot, V.; Rech, P.; Chriqui, D. Pluripotency of Arabidopsis Xylem Pericycle Underlies Shoot Regeneration from Root and Hypocotyl Explants Grown in Vitro. Plant J. 2009, 57, 626-644. [CrossRef] [PubMed]

16. Sugimoto, K.; Jiao, Y.; Meyerowitz, E.M. Arabidopsis Regeneration from Multiple Tissues Occurs via a Root Development Pathway. Dev. Cell 2010, 18, 463-471. [CrossRef] [PubMed]

17. Ikeuchi, M.; Sugimoto, K.; Iwase, A. Plant Callus: Mechanisms of Induction and Repression. Plant Cell 2013, 25, 3159-3173. [CrossRef]

18. Schaller, G.E.; Bishopp, A.; Kieber, J.J. The Yin-Yang of Hormones: Cytokinin and Auxin Interactions in Plant Development. Plant Cell 2015, 27, 44-63. [CrossRef] 
19. Swarup, R.; Kargul, J.; Marchant, A.; Zadik, D.; Rahman, A.; Mills, R.; Yemm, A.; May, S.; Williams, L.; Millner, P.; et al. Structure-Function Analysis of the Presumptive Arabidopsis Auxin Permease AUX1. Plant Cell 2004, 16, 3069-3083. [CrossRef]

20. Dindas, J.; Scherzer, S.; Roelfsema, M.R.G.; von Meyer, K.; Müller, H.M.; Al-Rasheid, K.A.S.; Palme, K.; Dietrich, P.; Becker, D.; Bennett, M.J.; et al. AUX1-Mediated Root Hair Auxin Influx Governs SCF ${ }^{T I R 1 / A F B}-T y p e ~ C a^{2+}$ Signaling. Nat. Commun. 2018, 9 , 1174. [CrossRef]

21. Hutchison, C.E.; Li, J.; Argueso, C.; Gonzalez, M.; Lee, E.; Lewis, M.W.; Maxwell, B.B.; Perdue, T.D.; Schaller, G.E.; Alonso, J.M.; et al. The Arabidopsis Histidine Phosphotransfer Proteins Are Redundant Positive Regulators of Cytokinin Signaling. Plant Cell 2006, 18, 3073-3087. [CrossRef]

22. Nguyen, K.H.; Ha, C.V.; Nishiyama, R.; Watanabe, Y.; Leyva-González, M.A.; Fujita, Y.; Tran, U.T.; Li, W.; Tanaka, M.; Seki, M.; et al. Arabidopsis Type B Cytokinin Response Regulators ARR1, ARR10, and ARR12 Negatively Regulate Plant Responses to Drought. Proc. Natl. Acad. Sci. USA 2016, 113, 3090-3095. [CrossRef]

23. Okushima, Y.; Overvoorde, P.J.; Arima, K.; Alonso, J.M.; Chan, A.; Chang, C.; Ecker, J.R.; Hughes, B.; Lui, A.; Nguyen, D.; et al. Functional Genomic Analysis of the AUXIN RESPONSE FACTOR Gene Family Members in Arabidopsis thatiana: Unique and Overlapping Functions of ARF7 and ARF19. Plant Cell 2005, 17, 444-463. [CrossRef] [PubMed]

24. Tiwari, S.B.; Wang, X.-J.; Hagen, G.; Guilfoyle, T.J. AUX/IAA Proteins Are Active Repressors, and Their Stability and Activity Are Modulated by Auxin. Plant Cell 2001, 13, 2809-2822. [CrossRef] [PubMed]

25. Gälweiler, L.; Guan, C.; Müller, A.; Wisman, E.; Mendgen, K.; Yephremov, A.; Palme, K. Regulation of Polar Auxin Transport by AtPIN1 in Arabidopsis Vascular Tissue. Science 1998, 282, 2226-2230. [CrossRef] [PubMed]

26. Ding, Z.; Wang, B.; Moreno, I.; Dupláková, N.; Simon, S.; Carraro, N.; Reemmer, J.; Pěnčík, A.; Chen, X.; Tejos, R.; et al. ER-Localized Auxin Transporter PIN8 Regulates Auxin Homeostasis and Male Gametophyte Development in Arabidopsis. Nat. Commun. 2012, 3, 941. [CrossRef] [PubMed]

27. Barbez, E.; Kubeš, M.; Rolčík, J.; Béziat, C.; Pěnčík, A.; Wang, B.; Rosquete, M.R.; Zhu, J.; Dobrev, P.I.; Lee, Y.; et al. A Novel Putative Auxin Carrier Family Regulates Intracellular Auxin Homeostasis in Plants. Nature 2012, 485, 119-122. [CrossRef] [PubMed]

28. Dewitte, W.; Scofield, S.; Alcasabas, A.A.; Maughan, S.C.; Menges, M.; Braun, N.; Collins, C.; Nieuwland, J.; Prinsen, E.; Sundaresan, V.; et al. Arabidopsis CYCD3 D-Type Cyclins Link Cell Proliferation and Endocycles and Are Rate-Limiting for Cytokinin Responses. Proc. Natl. Acad. Sci. USA 2007, 104, 14537-14542. [CrossRef]

29. Carpenter, E.J.; Matasci, N.; Ayyampalayam, S.; Wu, S.; Sun, J.; Yu, J.; Jimenez Vieira, F.R.; Bowler, C.; Dorrell, R.G.; Gitzendanner, M.A.; et al. Access to RNA-Sequencing Data from 1,173 Plant Species: The 1000 Plant Transcriptomes Initiative (1KP). GigaScience 2019, 8, giz126. [CrossRef]

30. Leebens-Mack, J.H.; Barker, M.S.; Carpenter, E.J.; Deyholos, M.K.; Gitzendanner, M.A.; Graham, S.W.; Grosse, I.; Li, Z.; Melkonian, M.; Mirarab, S.; et al. One Thousand Plant Transcriptomes and the Phylogenomics of Green Plants. Nature 2019, 574, 679-685. [CrossRef]

31. Benková, E.; Michniewicz, M.; Sauer, M.; Teichmann, T.; Seifertová, D.; Jürgens, G.; Friml, J. Local, Efflux-Dependent Auxin Gradients as a Common Module for Plant Organ Formation. Cell 2003, 115, 591-602. [CrossRef]

32. Xu, K.; Liu, J.; Fan, M.; Xin, W.; Hu, Y.; Xu, C. A Genome-Wide Transcriptome Profiling Reveals the Early Molecular Events during Callus Initiation in Arabidopsis Multiple Organs. Genomics 2012, 100, 116-124. [CrossRef] [PubMed]

33. Siwinska, J.; Siatkowska, K.; Olry, A.; Grosjean, J.; Hehn, A.; Bourgaud, F.; Meharg, A.A.; Carey, M.; Lojkowska, E.; Ihnatowicz, A. Scopoletin 8-Hydroxylase: A Novel Enzyme Involved in Coumarin Biosynthesis and Iron-Deficiency Responses in Arabidopsis. J. Exp. Bot. 2018, 69, 1735-1748. [CrossRef] [PubMed]

34. Rajniak, J.; Giehl, R.F.H.; Chang, E.; Murgia, I.; von Wirén, N.; Sattely, E.S. Biosynthesis of Redox-Active Metabolites in Response to Iron Deficiency in Plants. Nat. Chem. Biol. 2018, 14, 442-450. [CrossRef] [PubMed]

35. Hindt, M.N.; Guerinot, M.L. Getting a Sense for Signals: Regulation of the Plant Iron Deficiency Response. Biochim. Biophys. Acta 2012, 1823, 1521-1530. [CrossRef]

36. Fourcroy, P.; Sisó-Terraza, P.; Sudre, D.; Savirón, M.; Reyt, G.; Gaymard, F.; Abadía, A.; Abadia, J.; Álvarez-Fernández, A.; Briat, J.-F. Involvement of the ABCG37 Transporter in Secretion of Scopoletin and Derivatives by Arabidopsis Roots in Response to Iron Deficiency. New Phytol. 2014, 201, 155-167. [CrossRef]

37. Vanholme, R.; Sundin, L.; Seetso, K.C.; Kim, H.; Liu, X.; Li, J.; De Meester, B.; Hoengenaert, L.; Goeminne, G.; Morreel, K.; et al. COSY Catalyses Trans-Cis Isomerization and Lactonization in the Biosynthesis of Coumarins. Nat. Plants 2019, 5, 1066-1075. [CrossRef]

38. Murgia, I.; Tarantino, D.; Soave, C.; Morandini, P. Arabidopsis CYP82C4 Expression Is Dependent on Fe Availability and Circadian Rhythm, and Correlates with Genes Involved in the Early Fe Deficiency Response. J. Plant Physiol. 2011, 168, 894-902. [CrossRef] [PubMed]

39. Wu, X.R.; Kenzior, A.; Willmot, D.; Scanlon, S.; Chen, Z.; Topin, A.; He, S.H.; Acevedo, A.; Folk, W.R. Altered Expression of Plant Lysyl TRNA Synthetase Promotes TRNA Misacylation and Translational Recoding of Lysine. Plant J. 2007, 50, 627-636. [CrossRef]

40. Thimm, O.; Essigmann, B.; Kloska, S.; Altmann, T.; Buckhout, T.J. Response of Arabidopsis to Iron Deficiency Stress as Revealed by Microarray Analysis. Plant Physiol. 2001, 127, 1030-1043. [CrossRef]

41. Giritch, A.; Herbik, A.; Balzer, H.J.; Ganal, M.; Stephan, U.W.; Bäumlein, H. A Root-Specific Iron-Regulated Gene of Tomato Encodes a Lysyl-TRNA-Synthetase-like Protein. Eur. J. Biochem. 1997, 244, 310-317. [CrossRef] [PubMed] 
42. Brevet, A.; Chen, J.; Lévêque, F.; Plateau, P.; Blanquet, S. In Vivo Synthesis of Adenylylated Bis(5'-Nucleosidyl) Tetraphosphates (Ap4N) by Escherichia coli Aminoacyl-TRNA Synthetases. Proc. Natl. Acad. Sci. USA 1989, 86, 8275-8279. [CrossRef] [PubMed]

43. Lee, P.C.; Bochner, B.R.; Ames, B.N. Diadenosine 5',5'"'-P1,P4-Tetraphosphate and Related Adenylylated Nucleotides in Salmonella typhimurium. J. Biol. Chem. 1983, 258, 6827-6834. [CrossRef]

44. Baltzinger, M.; Ebel, J.P.; Remy, P. Accumulation of Dinucleoside Polyphosphates in Saccharomyces cerevisiae under Stress Conditions. High Levels Are Associated with Cell Death. Biochimie 1986, 68, 1231-1236. [CrossRef]

45. Pietrowska-Borek, M.; Nuc, K.; Zielezińska, M.; Guranowski, A. Diadenosine Polyphosphates (Ap3A and Ap4A) Behave as Alarmones Triggering the Synthesis of Enzymes of the Phenylpropanoid Pathway in Arabidopsis thaliana. FEBS Open Bio. 2011, 1, 1-6. [CrossRef] [PubMed]

46. Hernández-Morales, R.; Becerra, A.; Lazcano, A. Alarmones as Vestiges of a Bygone RNA World. J. Mol. Evol. 2019, 87, 37-51. [CrossRef]

47. He, D.; Zhang, H.; Yang, P. The Mitochondrion-Located Protein OsB12D1 Enhances Flooding Tolerance during Seed Germination and Early Seedling Growth in Rice. Int. J. Mol. Sci. 2014, 15, 13461-13481. [CrossRef]

48. Zheng, L.; Huang, F.; Narsai, R.; Wu, J.; Giraud, E.; He, F.; Cheng, L.; Wang, F.; Wu, P.; Whelan, J.; et al. Physiological and Transcriptome Analysis of Iron and Phosphorus Interaction in Rice Seedlings. Plant Physiol. 2009, 151, 262-274. [CrossRef]

49. Long, T.A.; Tsukagoshi, H.; Busch, W.; Lahner, B.; Salt, D.E.; Benfey, P.N. The BHLH Transcription Factor POPEYE Regulates Response to Iron Deficiency in Arabidopsis Roots. Plant Cell 2010, 22, 2219-2236. [CrossRef]

50. Siwinska, J.; Kadzinski, L.; Banasiuk, R.; Gwizdek-Wisniewska, A.; Olry, A.; Banecki, B.; Lojkowska, E.; Ihnatowicz, A. Identification of QTLs Affecting Scopolin and Scopoletin Biosynthesis in Arabidopsis thaliana. BMC Plant Biol. 2014, 14, 280. [CrossRef]

51. Kanai, M.; Hirai, M.; Yoshiba, M.; Tadano, T.; Higuchi, K. Iron Deficiency Causes Zinc Excess in Zea Mays. Soil Sci. Plant Nutr. 2009, 55, 271-276. [CrossRef]

52. Santos, C.S.; Ozgur, R.; Uzilday, B.; Turkan, I.; Roriz, M.; Rangel, A.O.S.S.; Carvalho, S.M.P.; Vasconcelos, M.W. Understanding the Role of the Antioxidant System and the Tetrapyrrole Cycle in Iron Deficiency Chlorosis. Plants 2019, 8, 348. [CrossRef] [PubMed]

53. Tsukagoshi, H.; Busch, W.; Benfey, P.N. Transcriptional Regulation of ROS Controls Transition from Proliferation to Differentiation in the Root. Cell 2010, 143, 606-616. [CrossRef] [PubMed]

54. Passardi, F.; Penel, C.; Dunand, C. Performing the Paradoxical: How Plant Peroxidases Modify the Cell Wall. Trends Plant Sci. 2004, 9, 534-540. [CrossRef] [PubMed]

55. Wagner, U.; Edwards, R.; Dixon, D.P.; Mauch, F. Probing the Diversity of the Arabidopsis Glutathione S-Transferase Gene Family. Plant Mol. Biol. 2002, 49, 515-532. [CrossRef]

56. Ugalde, J.M.; Lamig, L.; Herrera-Vásquez, A.; Fuchs, P.; Müller-Schüssele, S.J.; Meyer, A.J.; Holuigue, L. GSTU7 Affects Growth Performance and Acts as an Antagonist of Oxidative Stress Induced by Methyl Viologen. bioRxiv 2020. [CrossRef]

57. Sewelam, N.; Jaspert, N.; Van Der Kelen, K.; Tognetti, V.B.; Schmitz, J.; Frerigmann, H.; Stahl, E.; Zeier, J.; Van Breusegem, F.; Maurino, V.G. Spatial $\mathrm{H}_{2} \mathrm{O}_{2}$ Signaling Specificity: $\mathrm{H}_{2} \mathrm{O}_{2}$ from Chloroplasts and Peroxisomes Modulates the Plant Transcriptome Differentially. Mol. Plant 2014, 7, 1191-1210. [CrossRef]

58. Herrera-Vásquez, A.; Fonseca, A.; Ugalde, J.M.; Lamig, L.; Seguel, A.; Moyano, T.C.; Gutiérrez, R.A.; Salinas, P.; Vidal, E.A.; Holuigue, L. Transcription Factor TGA2 Is Essential for UV-B Stress Tolerance Controlling Oxidative Stress in Arabidopsis. bioRxiv 2020. [CrossRef]

59. Lee, K.; Park, O.-S.; Seo, P.J. RNA-Seq Analysis of the Arabidopsis Transcriptome in Pluripotent Calli. Mol. Cells 2016, 39, 484-494. [CrossRef]

60. Pičmanová, M.; Neilson, E.H.; Motawia, M.S.; Olsen, C.E.; Agerbirk, N.; Gray, C.J.; Flitsch, S.; Meier, S.; Silvestro, D.; Jørgensen, K.; et al. A Recycling Pathway for Cyanogenic Glycosides Evidenced by the Comparative Metabolic Profiling in Three Cyanogenic Plant Species. Biochem. J. 2015, 469, 375-389. [CrossRef]

61. Oracz, K.; El-Maarouf-Bouteau, H.; Kranner, I.; Bogatek, R.; Corbineau, F.; Bailly, C. The Mechanisms Involved in Seed Dormancy Alleviation by Hydrogen Cyanide Unravel the Role of Reactive Oxygen Species as Key Factors of Cellular Signaling during Germination. Plant Physiol. 2009, 150, 494-505. [CrossRef]

62. Caarls, L.; Van der Does, D.; Hickman, R.; Jansen, W.; Verk, M.C.V.; Proietti, S.; Lorenzo, O.; Solano, R.; Pieterse, C.M.J.; Van Wees, S.C.M. Assessing the Role of Ethylene Response Factor Transcriptional Repressors in Salicylic Acid-Mediated Suppression of Jasmonic Acid-Responsive Genes. Plant Cell Physiol. 2017, 58, 266-278. [CrossRef] [PubMed]

63. Sun, T.; Zhang, Y.; Li, Y.; Zhang, Q.; Ding, Y.; Zhang, Y. ChIP-Seq Reveals Broad Roles of SARD1 and CBP60g in Regulating Plant Immunity. Nat. Commun. 2015, 6, 10159. [CrossRef] [PubMed]

64. Li, J.; Brader, G.; Palva, E.T. The WRKY70 Transcription Factor: A Node of Convergence for Jasmonate-Mediated and SalicylateMediated Signals in Plant Defense. Plant Cell 2004, 16, 319-331. [CrossRef] [PubMed]

65. Zhou, M.; Lu, Y.; Bethke, G.; Harrison, B.T.; Hatsugai, N.; Katagiri, F.; Glazebrook, J. WRKY70 Prevents Axenic Activation of Plant Immunity by Direct Repression of SARD1. New Phytol. 2018, 217, 700-712. [CrossRef] [PubMed]

66. Lecourieux, D.; Mazars, C.; Pauly, N.; Ranjeva, R.; Pugin, A. Analysis and Effects of Cytosolic Free Calcium Increases in Response to Elicitors in Nicotiana plumbaginifolia Cells. Plant Cell 2002, 14, 2627-2641. [CrossRef] [PubMed]

67. Truman, W.; Sreekanta, S.; Lu, Y.; Bethke, G.; Tsuda, K.; Katagiri, F.; Glazebrook, J. The CALMODULIN-BINDING PROTEIN60 Family Includes Both Negative and Positive Regulators of Plant Immunity. Plant Physiol. 2013, 163, 1741-1751. [CrossRef] 
68. Lian, K.; Gao, F.; Sun, T.; van Wersch, R.; Ao, K.; Kong, Q.; Nitta, Y.; Wu, D.; Krysan, P.; Zhang, Y. MKK6 Functions in Two Parallel MAP Kinase Cascades in Immune Signaling. Plant Physiol. 2018, 178, 1284-1295. [CrossRef]

69. Fukunaga, S.; Sogame, M.; Hata, M.; Singkaravanit-Ogawa, S.; Piślewska-Bednarek, M.; Onozawa-Komori, M.; Nishiuchi, T.; Hiruma, K.; Saitoh, H.; Terauchi, R.; et al. Dysfunction of Arabidopsis MACPF Domain Protein Activates Programmed Cell Death via Tryptophan Metabolism in MAMP-Triggered Immunity. Plant J. 2017, 89, 381-393. [CrossRef]

70. Ge, X.; Li, G.-J.; Wang, S.-B.; Zhu, H.; Zhu, T.; Wang, X.; Xia, Y. AtNUDT7, a Negative Regulator of Basal Immunity in Arabidopsis, Modulates Two Distinct Defense Response Pathways and Is Involved in Maintaining Redox Homeostasis. Plant Physiol. 2007, 145, 204-215. [CrossRef]

71. Bacete, L.; Mélida, H.; Miedes, E.; Molina, A. Plant Cell Wall-Mediated Immunity: Cell Wall Changes Trigger Disease Resistance Responses. Plant J. 2018, 93, 614-636. [CrossRef] [PubMed]

72. He, Z.H.; Cheeseman, I.; He, D.; Kohorn, B.D. A Cluster of Five Cell Wall-Associated Receptor Kinase Genes, Wak1-5, Are Expressed in Specific Organs of Arabidopsis. Plant Mol. Biol. 1999, 39, 1189-1196. [CrossRef] [PubMed]

73. Kohorn, B.D.; Johansen, S.; Shishido, A.; Todorova, T.; Martinez, R.; Defeo, E.; Obregon, P. Pectin Activation of MAP Kinase and Gene Expression Is WAK2 Dependent. Plant J. 2009, 60, 974-982. [CrossRef]

74. Hartmann, M.; Zeier, J. N-Hydroxypipecolic Acid and Salicylic Acid: A Metabolic Duo for Systemic Acquired Resistance. Curr. Opin. Plant Biol. 2019, 50, 44-57. [CrossRef] [PubMed]

75. Hartmann, M.; Zeier, T.; Bernsdorff, F.; Reichel-Deland, V.; Kim, D.; Hohmann, M.; Scholten, N.; Schuck, S.; Bräutigam, A.; Hölzel, T.; et al. Flavin Monooxygenase-Generated N-Hydroxypipecolic Acid Is a Critical Element of Plant Systemic Immunity. Cell 2018, 173, 456-469.e16. [CrossRef] [PubMed]

76. Yadav, V.; Wang, Z.; Wei, C.; Amo, A.; Ahmed, B.; Yang, X.; Zhang, X. Phenylpropanoid Pathway Engineering: An Emerging Approach towards Plant Defense. Pathogens 2020, 9, 312. [CrossRef] [PubMed]

77. Ismond, K.P.; Dolferus, R.; De Pauw, M.; Dennis, E.S.; Good, A.G. Enhanced Low Oxygen Survival in Arabidopsis through Increased Metabolic Flux in the Fermentative Pathway. Plant Physiol. 2003, 132, 1292-1302. [CrossRef]

78. Kerpen, L.; Niccolini, L.; Licausi, F.; van Dongen, J.T.; Weits, D.A. Hypoxic Conditions in Crown Galls Induce Plant Anaerobic Responses That Support Tumor Proliferation. Front. Plant Sci. 2019, 10, 56. [CrossRef]

79. Maruta, T.; Yonemitsu, M.; Yabuta, Y.; Tamoi, M.; Ishikawa, T.; Shigeoka, S. Arabidopsis Phosphomannose Isomerase 1, but Not Phosphomannose Isomerase 2, Is Essential for Ascorbic Acid Biosynthesis. J. Biol. Chem. 2008, 283, 28842-28851. [CrossRef]

80. Turk, E.M.; Fujioka, S.; Seto, H.; Shimada, Y.; Takatsuto, S.; Yoshida, S.; Denzel, M.A.; Torres, Q.I.; Neff, M.M. CYP72B1 Inactivates Brassinosteroid Hormones: An Intersection between Photomorphogenesis and Plant Steroid Signal Transduction. Plant Physiol. 2003, 133, 1643-1653. [CrossRef]

81. Mudgil, Y.; Uhrig, J.F.; Zhou, J.; Temple, B.; Jiang, K.; Jones, A.M. Arabidopsis N-MYC DOWNREGULATED-LIKE1, a Positive Regulator of Auxin Transport in a G Protein-Mediated Pathway. Plant Cell 2009, 21, 3591-3609. [CrossRef]

82. Urbanowicz, B.R.; Bennett, A.B.; del Campillo, E.; Catalá, C.; Hayashi, T.; Henrissat, B.; Höfte, H.; McQueen-Mason, S.J.; Patterson, S.E.; Shoseyov, O.; et al. Structural Organization and a Standardized Nomenclature for Plant Endo-1,4- $\beta$-Glucanases (Cellulases) of Glycosyl Hydrolase Family 9. Plant Physiol. 2007, 144, 1693-1696. [CrossRef] [PubMed]

83. Shani, Z.; Dekel, M.; Roiz, L.; Horowitz, M.; Kolosovski, N.; Lapidot, S.; Alkan, S.; Koltai, H.; Tsabary, G.; Goren, R.; et al. Expression of Endo-1,4-Beta-Glucanase (Cel1) in Arabidopsis thaliana Is Associated with Plant Growth, Xylem Development and Cell Wall Thickening. Plant Cell Rep. 2006, 25, 1067-1074. [CrossRef] [PubMed]

84. Tsabary, G.; Shani, Z.; Roiz, L.; Levy, I.; Riov, J.; Shoseyov, O. Abnormal 'wrinkled' Cell Walls and Retarded Development of Transgenic Arabidopsis thaliana Plants Expressing Endo-1,4- $\beta$-Glucanase (Cell) Antisense. Plant Mol. Biol. 2003, 51, 213-224. [CrossRef]

85. Majda, M.; Robert, S. The Role of Auxin in Cell Wall Expansion. Int. J. Mol. Sci. 2018, 19, 951. [CrossRef] [PubMed]

86. Takahashi, E.; Ma, J.F.; Miyake, Y. The Possibility of Silicon as an Essential Element for Higher Plants. Comments Agric. Food Chem. 1990, 2, 99-102.

87. Spartz, A.K.; Ren, H.; Park, M.Y.; Grandt, K.N.; Lee, S.H.; Murphy, A.S.; Sussman, M.R.; Overvoorde, P.J.; Gray, W.M. SAUR Inhibition of PP2C-D Phosphatases Activates Plasma Membrane H+-ATPases to Promote Cell Expansion in Arabidopsis. Plant Cell 2014, 26, 2129-2142. [CrossRef]

88. Cosgrove, D.J. Cell Wall Loosening by Expansins1. Plant Physiol. 1998, 118, 333-339. [CrossRef]

89. Wolf, S.; Mouille, G.; Pelloux, J. Homogalacturonan Methyl-Esterification and Plant Development. Mol. Plant 2009, 2, 851-860. [CrossRef]

90. Sénéchal, F.; Wattier, C.; Rustérucci, C.; Pelloux, J. Homogalacturonan-Modifying Enzymes: Structure, Expression, and Roles in Plants. J. Exp. Bot. 2014, 65, 5125-5160. [CrossRef]

91. Kanter, U.; Usadel, B.; Guerineau, F.; Li, Y.; Pauly, M.; Tenhaken, R. The Inositol Oxygenase Gene Family of Arabidopsis Is Involved in the Biosynthesis of Nucleotide Sugar Precursors for Cell-Wall Matrix Polysaccharides. Planta 2005, 221, 243-254. [CrossRef]

92. Lorence, A.; Chevone, B.I.; Mendes, P.; Nessler, C.L. Myo-Inositol Oxygenase Offers a Possible Entry Point into Plant Ascorbate Biosynthesis. Plant Physiol. 2004, 134, 1200-1205. [CrossRef]

93. Ivanov Kavkova, E.; Blöchl, C.; Tenhaken, R. The Myo-inositol Pathway Does Not Contribute to Ascorbic Acid Synthesis. Plant Biol. 2019, 21, 95-102. [CrossRef]

94. Campbell, R.E.; Sala, R.F.; van de Rijn, I.; Tanner, M.E. Properties and Kinetic Analysis of UDP-Glucose Dehydrogenase from Group A Streptococci. Irreversible Inhibition by UDP-Chloroacetol. J. Biol. Chem. 1997, 272, 3416-3422. [CrossRef] [PubMed] 
95. Cruz-Valderrama, J.E.; Gómez-Maqueo, X.; Salazar-Iribe, A.; Zúñiga-Sánchez, E.; Hernández-Barrera, A.; Quezada-Rodríguez, E.; Gamboa-deBuen, A. Overview of the Role of Cell Wall DUF642 Proteins in Plant Development. Int. J. Mol. Sci. 2019, $20,3333$. [CrossRef]

96. Zúñiga-Sánchez, E.; Soriano, D.; Martínez-Barajas, E.; Orozco-Segovia, A.; Gamboa-deBuen, A. BIIDXI, the At4g32460 DUF642 Gene, Is Involved in Pectin Methyl Esterase Regulation during Arabidopsis thaliana Seed Germination and Plant Development. BMC Plant Biol. 2014, 14, 338. [CrossRef] [PubMed]

97. Garza-Caligaris, L.E.; Avendaño-Vázquez, A.O.; Alvarado-López, S.; Zúñiga-Sánchez, E.; Orozco-Segovia, A.; Pérez-Ruíz, R.V.; Gamboa-deBuen, A. At3g08030 Transcript: A Molecular Marker of Seed Ageing. Ann. Bot. 2012, 110, 1253-1260. [CrossRef]

98. Zell, M.B.; Fahnenstich, H.; Maier, A.; Saigo, M.; Voznesenskaya, E.V.; Edwards, G.E.; Andreo, C.; Schleifenbaum, F.; Zell, C.; Drincovich, M.F.; et al. Analysis of Arabidopsis with Highly Reduced Levels of Malate and Fumarate Sheds Light on the Role of These Organic Acids as Storage Carbon Molecules. Plant Physiol. 2010, 152, 1251-1262. [CrossRef] [PubMed]

99. Galuszka, P.; Popelková, H.; Werner, T.; Frébortová, J.; Pospíšilová, H.; Mik, V.; Köllmer, I.; Schmülling, T.; Frébort, I. Biochemical Characterization of Cytokinin Oxidases/Dehydrogenases from Arabidopsis thaliana Expressed in Nicotiana tabacum L. J. Plant Growth Regul. 2007, 26, 255-267. [CrossRef]

100. Kurakawa, T.; Ueda, N.; Maekawa, M.; Kobayashi, K.; Kojima, M.; Nagato, Y.; Sakakibara, H.; Kyozuka, J. Direct Control of Shoot Meristem Activity by a Cytokinin-Activating Enzyme. Nature 2007, 445, 652-655. [CrossRef] [PubMed]

101. Balcerowicz, D.; Schoenaers, S.; Vissenberg, K. Cell Fate Determination and the Switch from Diffuse Growth to Planar Polarity in Arabidopsis Root Epidermal Cells. Front. Plant Sci. 2015, 6, 1163. [CrossRef]

102. Kuczak, M.; Kurczyńska, E. Cell Wall Composition as a Marker of the Reprogramming of the Cell Fate on the Example of a Daucus carota (L.) Hypocotyl in Which Somatic Embryogenesis Was Induced. Int. J. Mol. Sci. 2020, $21,8126$. [CrossRef] [PubMed]

103. Roldán-Arjona, T.; Ariza, R.R.; Córdoba-Cañero, D. DNA Base Excision Repair in Plants: An Unfolding Story With Familiar and Novel Characters. Front. Plant Sci. 2019, 10, 1055. [CrossRef] [PubMed]

104. Shim, S.; Lee, H.G.; Park, O.-S.; Shin, H.; Lee, K.; Lee, H.; Huh, J.H.; Seo, P.J. Dynamic Changes in DNA Methylation Occur in TE Regions and Affect Cell Proliferation during Leaf-to-Callus Transition in Arabidopsis. Epigenetics 2021, 1-18. [CrossRef] [PubMed]

105. He, C.; Chen, X.; Huang, H.; Xu, L. Reprogramming of H3K27me3 Is Critical for Acquisition of Pluripotency from Cultured Arabidopsis Tissues. PLoS Genet. 2012, 8, e1002911. [CrossRef]

106. Schumann, U.; Lee, J.M.; Smith, N.A.; Zhong, C.; Zhu, J.-K.; Dennis, E.S.; Millar, A.A.; Wang, M.-B. DEMETER Plays a Role in DNA Demethylation and Disease Response in Somatic Tissues of Arabidopsis. Epigenetics 2019, 14, 1074-1087. [CrossRef]

107. Taylor, N.G.; Laurie, S.; Turner, S.R. Multiple Cellulose Synthase Catalytic Subunits Are Required for Cellulose Synthesis in Arabidopsis. Plant Cell 2000, 12, 2529-2540. [CrossRef]

108. Tucker, M.R.; Lou, H.; Aubert, M.K.; Wilkinson, L.G.; Little, A.; Houston, K.; Pinto, S.C.; Shirley, N.J. Exploring the Role of Cell Wall-Related Genes and Polysaccharides during Plant Development. Plants 2018, 7, 42. [CrossRef]

109. Grafi, G. How Cells Dedifferentiate: A Lesson from Plants. Dev. Biol. 2004, 268, 1-6. [CrossRef]

110. Harikrishna, K.; Darby, R.; Draper, J. Chloroplast Dedifferentiation in Mechanically Isolated Asparagus Cells during Culture Initiation. Plant Physiol. 1992, 100, 1177-1183. [CrossRef]

111. Backes, A.; Behr, M.; Xu, X.; Gatti, E.; Legay, S.; Predieri, S.; Hausman, J.-F.; Deyholos, M.K.; Cai, G.; Guerriero, G. Sucrose Synthase Gene Expression Analysis in the Fibre Nettle (Urtica dioica L.) Cultivar "Clone 13". Ind. Crop. Prod. 2018, 123, 315-322. [CrossRef]

112. Mortazavi, A.; Williams, B.A.; McCue, K.; Schaeffer, L.; Wold, B. Mapping and Quantifying Mammalian Transcriptomes by RNA-Seq. Nat. Methods 2008, 5, 621-628. [CrossRef]

113. Shannon, P.; Markiel, A.; Ozier, O.; Baliga, N.S.; Wang, J.T.; Ramage, D.; Amin, N.; Schwikowski, B.; Ideker, T. Cytoscape: A Software Environment for Integrated Models of Biomolecular Interaction Networks. Genome Res. 2003, 13, $2498-2504$. [CrossRef] [PubMed]

114. Bindea, G.; Mlecnik, B.; Hackl, H.; Charoentong, P.; Tosolini, M.; Kirilovsky, A.; Fridman, W.-H.; Pagès, F.; Trajanoski, Z.; Galon, J. ClueGO: A Cytoscape Plug-in to Decipher Functionally Grouped Gene Ontology and Pathway Annotation Networks. Bioinformatics 2009, 25, 1091-1093. [CrossRef] [PubMed]

115. Ge, S.X.; Son, E.W.; Yao, R. IDEP: An Integrated Web Application for Differential Expression and Pathway Analysis of RNA-Seq Data. BMC Bioinform. 2018, 19, 534. [CrossRef] [PubMed]

116. Eisen, M.B.; Spellman, P.T.; Brown, P.O.; Botstein, D. Cluster Analysis and Display of Genome-Wide Expression Patterns. Proc. Natl. Acad. Sci. USA 1998, 95, 14863-14868. [CrossRef]

117. Saldanha, A.J. Java Treeview-Extensible Visualization of Microarray Data. Bioinformatics 2004, 20, 3246-3248. [CrossRef] 